\title{
Recovery Plan for Laurel Wilt on Redbay and Other Forest Species Caused by Raffaelea lauricola and Disseminated by Xyleborus glabratus
}

Updated May 2015

M. A. Hughes and J. A. Smith, School of Forest Resources and Conservation, University of Florida, Gainesville 32611; R. C. Ploetz, Tropical Research \& Education Center, Homestead, University of Florida, Homestead 33031; P. E. Kendra, USDA-ARS Subtropical Horticulture Research Station, Miami, FL 33158; A. E. Mayfield III, USDA Forest Service, Southern Research Station, Asheville, NC 28804; J. L. Hanula, USDA Forest Service, Southern Research Station, Athens, GA 30602; J. Hulcr, School of Forest Resources and Conservation and Department of Entomology and Nematology, University of Florida, Gainesville 32611; L. L. Stelinski, Citrus Research and Education Center, University of Florida, Lake Alfred 33850; S. Cameron, Georgia Forestry Commission, Richmond Hill 31324; J. J. Riggins, Department of Biochemistry, Molecular Biology, Entomology, and Plant Pathology, Mississippi State University, Mississippi State 39762; D. Carrillo, Tropical Research and Education Center, University of Florida, Homestead 33031; R. Rabaglia, USDA Forest Service, Forest Health Protection, Washington, DC 20250; J. Eickwort, Forest Health Section, Florida Forest Service, Gainesville, FL 32608; T. Pernas, National Park Service, Palmetto Bay, FL 33157

Accepted for publication 13 October 2015. Published 17 November 2015.

Hughes, M. A., Smith, J. A., Ploetz, R. C., Kendra, P. E., Mayfield A. E., III, Hanula, J. L., Hulcr, J., Stelinski, L. L., Cameron, S., Riggins, J. J., Carrillo, D., Rabaglia, R., Eickwort, J., and Pernas, T. 2015. Recovery plan for laurel wilt on redbay and other forest species caused by Raffaelea lauricola and disseminated by Xyleborus glabratus. Plant Health Progress doi:10.1094/PHP-RP-15-0017.

Table of Contents

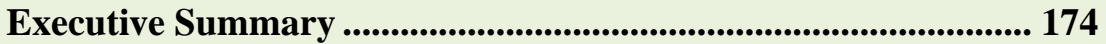

I. Introduction ..................................................................................... 175

II. Disease Cycle and Symptom Development .............................. 178

III. Spread ................................................................................................ 186

IV. Monitoring and Detection.......................................................... 187

V. Response ............................................................................................. 189

VI. Permits and Regulatory Issues .............................................. 191

VII. Cultural, Economic and Ecological Impacts ........................... 191

VIII. Mitigation and Disease Management....................................... 194

IX. Research, Extension, and Education Needs............................ 199

X. References ............................................................................ 200

XI. Infrastructure and Experts ...................................................... 205

XII. Web Resources........................................................................... 209

Corresponding author: Jason A. Smith Email: jasons@ufl.edu

doi:10.1094/PHP-RP-15-0017

This article is in the public domain and not copyrightable.

It may be freely reprinted with customary crediting of the source.

The American Phytopathological Society, 2015 
This recovery plan is one of several disease-specific documents produced as part of the National Plant Disease Recovery System (NPDRS) called for in Homeland Security Presidential Directive Number 9 (HSPD-9). The purpose of the NPDRS is to insure that the tools, infrastructure, communication networks, and capacity required to mitigate the impact of high-consequence plant disease outbreaks are such that a reasonable level of crop production is maintained.

Each disease-specific plan is intended to provide a brief primer on the disease, assess the status of critical recovery components, and identify disease management research, extension, and education needs. These documents are not intended to be stand-alone documents that address all of the many and varied aspects of plant disease outbreak and all of the decisions that must be made and actions taken to achieve effective response and recovery. They are, however, documents that will help USDA guide further efforts directed toward plant disease recovery.

\section{Executive Summary}

Laurel wilt is a highly destructive disease affecting members of the Lauraceae in the United States. The insect vector, the redbay ambrosia beetle (Xyleborus glabratus) was first captured in monitoring traps near Port Wentworth, GA, in 2002 and first reported associated with mortality of redbay (Persea borbonia) trees in 2003. Laurel wilt disease is initiated when X. glabratus introduces its fungal symbiont (Raffaelea lauricola) into the sapwood of host trees. The fungus is carried within specialized pouches (mandibular mycangia) near the beetle's mouthparts, where it lives in a budding, yeast-like state. The fungal spores are introduced into the xylem as the beetle bores into the stem, leaving typical evidence of ambrosia beetle attack (small holes and boring dust). Host trees react to the fungal invasion with the production of gums and tyloses, which block water transport and cause crown wilt. Upon dissection of infected wood, xylem discoloration is readily evident.

Laurel wilt has now been detected in eight southeastern states (Alabama, Florida, Georgia, Louisiana, Mississippi, North Carolina, South Carolina, and Texas), causing significant mortality to redbay populations. Redbay serves an important ecological role in forests, and the loss of this species has had significant effects on forest composition. Several other lauraceous hosts [sassafras (Sassafras albidum), silk bay (Persea humilis), swamp bay (Persea palustris), pondspice (Litsea aestivalis) (state endangered), and pondberry (Lindera melissifolia) (federally endangered)] are susceptible to laurel wilt and have been affected by the disease to varying degrees. In addition, agricultural [avocado (Persea americana)] and ornamental non-native members of the Lauraceae within the United States are susceptible.

Eradication of the vector and pathogen is improbable due to the ability of the vector to persist in small-diameter stems and of a few females to establish new populations. Currently, management options within a natural forest setting are limited and spread of the disease into new areas (e.g., California, Mexico, and Central and South America) remains a threat. For these reasons, it is essential to continue to monitor the spread of the disease and to continue to develop a better understanding of the biology of the beetle and pathogen as well as the epidemiology of the disease. In addition, further development of the following strategies may help to reduce the impact of laurel wilt in forests and urban settings, and limit the spread of the disease:

- minimization of human-aided transport of firewood and unprocessed wood materials, a mechanism for long-distance movement of the disease;

- utilization of chemical options (fungicides and possibly insecticides) for the protection of high-value trees;

- continued development of resistant host-plant cultivars for landscape use and restoration; 
- collection and maintenance of germplasm of vulnerable hosts, especially

rare species that may be in danger of extinction;

- continued research on disease biology, vector chemical ecology, alternative disease pathways and vectors, management options, and natural enemies, and

- continued efforts to educate the public about the potential cultural, economic, and ecological effects of laurel wilt.

\section{Introduction}

Laurel wilt is a disease of shrubs and trees within the plant family Lauraceae. The fungal pathogen (Raffaelea lauricola T.C. Harr., Fraedrich \& Aghayeva) is transmitted into the host xylem by the redbay ambrosia beetle (Xyleborus glabratus Eichhoff) when the beetle bores into trunks or large stems (Harrington et al. 2008). Xyleborus glabratus and $R$. lauricola are both exotic organisms in the USA, presumably transported within solid wood packing material prior to the beetle's first detection in Port Wentworth, GA, in 2002 (Fraedrich et al. 2008). Laurel wilt has caused a reduction in redbay (Persea borbonia (L.) Spreng.) populations within forests of the southeastern United States, with mortality of redbay and other host species recorded in eight states (Alabama, Florida, Georgia, Louisiana, Mississippi, North Carolina, South Carolina, and Texas). Within weeks to months of inoculation by the beetle, infected redbay trees will display wilt in a portion of the canopy that subsequently extends to the entire crown; upon death, the trees become suitable substrates for reproduction of $X$. glabratus (Fraedrich et al. 2008).

Xyleborus glabratus is native to southern Asia (India, Bangladesh, Myanmar, Japan, Taiwan, and China) (Rabaglia et al. 2006; Hulcr and Lou 2013). Raffaelea lauricola has been isolated from beetles from Japan and Taiwan, suggesting that their symbiotic relationship occurs within their native range (Harrington et al. 2011; J. Hulcr unpublished). In the United States, X. glabratus has only been recorded in plants within the Lauraceae; although $R$. lauricola has also been recovered from additional ambrosia beetle species (Carrillo et al. 2014) and also live oak (Quercus virginiana Mill.) (J. Smith, personal communication). Specimen records suggest that $X$. glabratus also strongly prefers lauraceous hosts in its native range, although it has also been collected from species in the Dipterocarpaceae, Fagaceae, Fabaceae, Theaceae, and Pinaceae (Rabaglia et al. 2006; Hulcr and Lou 2013).

Laurel wilt has affected most native and several cultivated nonnative species of Lauraceae within the southeastern United States. Raffaelea lauricola has been recovered from symptomatic forest and landscape plants and Koch's postulates completed for nine hosts (Table 1). Five potential hosts have not been infected in the landscape; however, laurel wilt symptom development has occurred after artificial inoculation with $R$. lauricola (Table 2).

Redbay ( $P$. borbonia sensu stricto) is an aromatic evergreen tree with leathery leaves that often forms a dense and rounded crown. Redbay, swamp bay (Persea palustris (Raf.) Sarg), and silk bay (Persea humilis Nash) are often grouped together as a single species called redbay (sensu lato); however, differences exist in morphology, canopy architecture, and habitat (Coder 2012), as well as in secondary metabolites (Niogret et al. 2011). Within this document, the term redbay refers to the broader species complex (P. borbonia, P. palustris, and P. humilis), while P. borbonia will be referred to as redbay (s.s) (s.s. = sensu stricto abbreviated). Redbay (s.s) is the species most affected by laurel wilt. The disease spreads rapidly within stands, and typically the majority of mature redbay (s.s) trees in an area die within a few years (Fraedrich et al. 2008; Shield et al. 2011; Cameron et al. 2012; Evans et al. 2013; Spiegel and Leege 2013). In newly infested sites, X. glabratus will preferentially attack large-diameter trees but also infests smaller trees, with most attacks concentrating on the lower bole (Fraedrich et al. 2008; Maner et al. 2012; Kendra et al. 


\section{Host $^{\mathrm{a}}$}

Persea borbonia (L.) Spreng. (Redbay)

Persea palustris (Raf.) Sarg (Swamp bay)

Sassafras albidum (Nutt.) Nees (Sassafras)

Persea americana Mill. (Avocado) ${ }^{\mathrm{b}}$

Litsea aestivalis (L.) Fernald (Pondspice) ${ }^{\mathrm{c}}$

Lindera melissifolia (Walter) Blume (Pondberry) ${ }^{\mathrm{c}}$

Persea humilis Nash (Silk bay)

Laurus nobilis (L.) (Bay laurel) ${ }^{\mathrm{b}}$

Cinnamomum camphora (L.) J. Presl (Camphortree) ${ }^{\mathrm{b}}$

\section{Reference}

Fraedrich et al. 2008

Fraedrich et al. 2008

Fraedrich et al. 2008

Mayfield et al. 2008a

Hughes et al. 2011

Fraedrich et al. 2011

Hughes et al. 2012

Hughes et al. 2014

Fraedrich et al. 2015

a Plant names derived from The PLANTS Database (http://plants.usda.gov) and The

Plant List (2013), Version 1.1. (http://www.theplantlist.org).

${ }^{b}$ Non-native, landscape or agricultural species.

${ }^{\mathrm{c}}$ Indicates threatened or endangered status (state or federally).

\begin{tabular}{|c|c|}
\hline \multicolumn{2}{|c|}{$\begin{array}{l}\text { TABLE } 2 \\
\text { Tree species displaying laurel wilt symptoms after } \\
\text { artificial inoculation with } R \text {. Iauricola, yet lacking } \\
\text { documented cases of laurel wilt in the wild. }\end{array}$} \\
\hline Host $^{a}$ & Reference \\
\hline $\begin{array}{l}\text { Umbellularia californica (Hook. \& Arn.) Nutt. } \\
\text { (California laurel) }\end{array}$ & Fraedrich 2008 \\
\hline Lindera benzoin (L.) Blume (Northern spicebush) & Fraedrich et al. 2008 \\
\hline $\begin{array}{l}\text { Licaria triandra }(\mathrm{Sw} .) \text { Kosterm. } \\
\text { (Pepperleaf sweetwood) }^{\mathrm{c}}\end{array}$ & Ploetz and Konkol 2013 \\
\hline Persea indica (L.) Spreng. (Viñátigo [Spanish]) ${ }^{b}$ & Hughes et al. 2013 \\
\hline Nectandra coriacea (Sw.) Griseb. (Lancewood) & Hughes \& Ploetz, unpublished \\
\hline \multicolumn{2}{|c|}{$\begin{array}{l}\text { a Plant names derived from The PLANTS Database (http://plants.usda.gov) and The } \\
\text { Plant List (2013), Version 1.1. (http://www.theplantlist.org). }\end{array}$} \\
\hline${ }^{\mathrm{b}}$ Non-native, landscape or agricultural species. & \\
\hline
\end{tabular}

2013a; Mayfield and Brownie 2013). Dispersing beetles are attracted to host volatiles (Hanula and Sullivan 2008; Kendra et al. 2011, 2012b; Niogret et al. 2011; Kuhns et al. 2014a, Martini et al. 2015) and also use stem silhouettes as visual cues (Mayfield and Brownie 2013) when finding host trees.

Laurel wilt of avocado (Persea americana Mill.) was first observed in residential areas near Jacksonville, FL, in 2007 (Mayfield et al. 2008a), and in 2012 was first observed in the avocado production areas of Miami-Dade County (Ploetz et al. 2013). A separate recovery plan for laurel wilt in avocado was prepared (Ploetz et al. 2011a), and is being revised.

The development of laurel wilt in sassafras (Sassafras albidum (Nutt.) Nees) is slightly different than in the redbay species complex, perhaps because it is deciduous and can propagate from interconnected root sprouts. Leaves of affected sassafras display a transition from green to brown followed by wilt and defoliation (Fig. 1), while in redbay the wilted leaves often remain attached for long periods of time. If infected in early spring, leaf expansion may cease, resulting in stunted foliage, followed by wilting and defoliation. The presence of dark vascular discoloration in lateral roots of infected sassafras (Fig. 1C), along with the directional movement of laurel wilt among thickets without evidence of $X$. glabratus attacks, suggests underground transmission of the pathogen through roots (Cameron et al. 2010, 2012). 


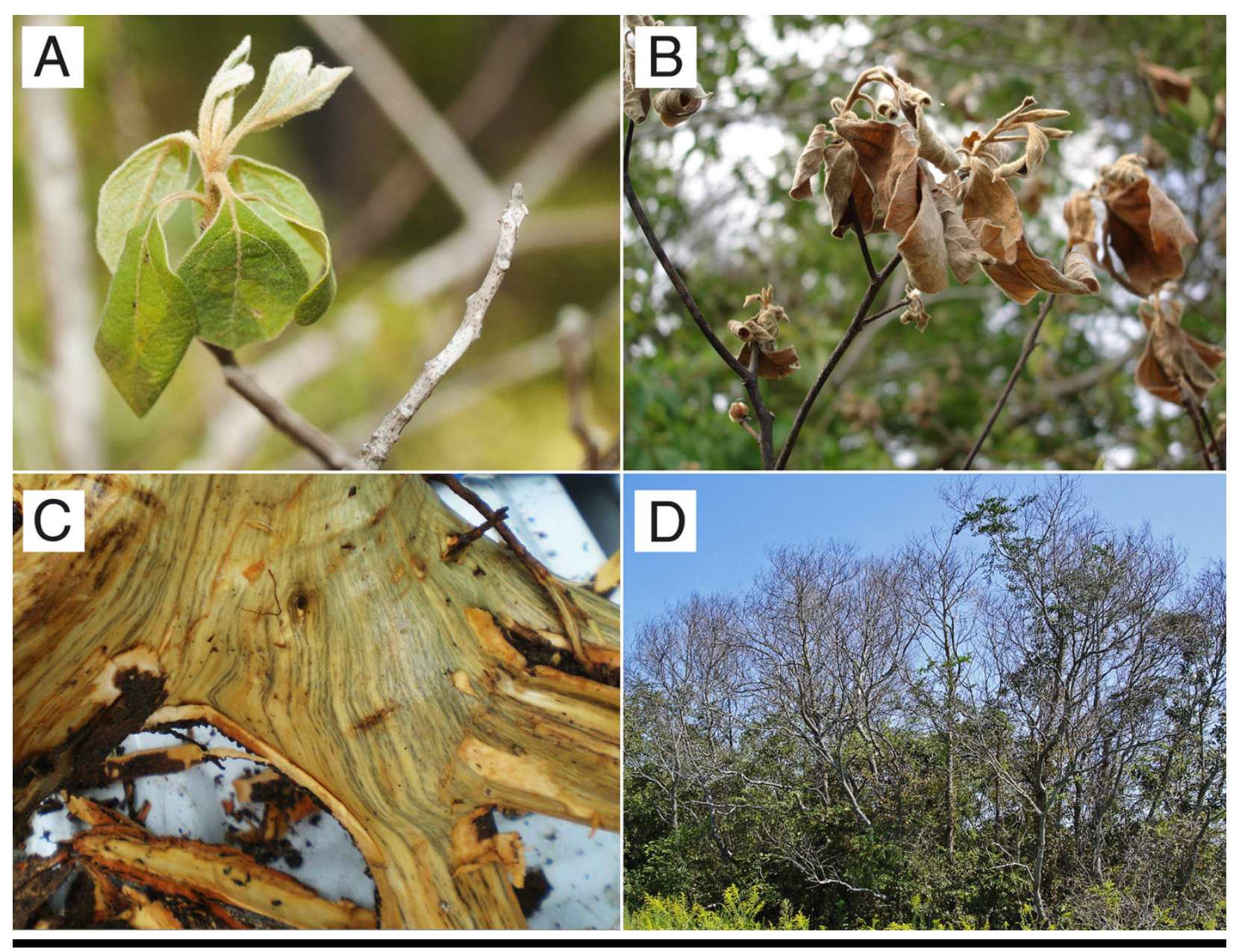

FIGURE 1

Laurel wilt development in sassafras: (A) Green, wilted foliage, that progresses to (B) brown wilted foliage, (C) sapwood discoloration on root flare, and (D) standing, defoliated trees. Photos by Scott Cameron (A, B, D) and Chip Bates (C), Georgia Forestry Commission.

Laurel wilt has caused mortality to the federally endangered pondberry (Lindera melissifolia (Walter) Blume) (Georgia and South Carolina) and the state threatened/ endangered pondspice (Litsea aestivalis (L.) Fernald) (Georgia, South Carolina, and Florida), with $X$. glabratus brood production confirmed within pondspice (Fraedrich et al. 2011; Hughes et al. 2011). Although these shrubs are considered suboptimal hosts for X. glabratus, owing to their small-diameter stems (Fraedrich et al. 2011), their ultimate fate remains uncertain.

Branch dieback due to laurel wilt was confirmed in camphortree (Cinnamomum camphora (L.) J. Presl) in Florida and Georgia; however, mortality in this Asian species has been limited (Cameron et al. 2008; Smith et al. 2009; Fraedrich et al. 2015). Raffaelea lauricola moved systemically in the xylem of camphortree after artificial inoculation, and multiple stem infections caused mortality in saplings (Fraedrich et al. 2015). Presumably, this species co-evolved with the beetle and fungus in Asia, and therefore has more tolerance than naive North American hosts.

A single bay laurel (Laurus nobilis (L.)) located near a recently wilted avocado in Gainesville, FL, also succumbed to laurel wilt in 2013 (Hughes et al. 2014). Bay laurel is a small to moderate-sized tree that is native to areas of the southern Mediterranean and planted in residential areas of the United States as an ornamental because of its attractive form and culinary use of leaves. Artificial inoculations have confirmed the susceptibility of bay laurel (Hughes et al. 2014), but the fate of this tree 
as a cultivated species or as a member of native forests in the Mediterranean is unknown.

In order to predict future host range expansions, inoculation experiments with other lauraceous plants have been conducted. Northern spicebush (Lindera benzoin (L.) Blume), lancewood (Nectandra coriacea (Sw.) Griseb.), and pepperleaf sweetwood/Gulf Licaria (Licaria triandra (Sw.) Kosterm.) are species within the current geographic range of laurel wilt that have shown varying levels of symptom development following artificial inoculation. Pepperleaf sweetwood/Gulf licaria is a federally endangered species, with a natural population of less than 12 trees found within Miami-Dade County (Surdick and Jenkins 2010; Ploetz and Konkol 2013), and therefore any mortality of this species would be ecologically significant. Potted California laurel (Umbellularia californica (Hook. \& Arn.) Nutt.) seedlings exhibited susceptibility to $R$. lauricola, and bolts from trees attracted X. glabratus in field experiments and supported vector reproduction. This suggests that California laurel may be a viable host should $X$. glabratus invade the western United States (Fraedrich 2008; Mayfield et al. 2013). Viñátigo (Persea indica (L.) Spreng.), a dominant member of the fragile laurel cloud forests of the Madeira and Canary Islands, and an ornamental used in areas of the USA and Spain with Mediterranean-like climates, was also reported to be attractive to $X$. glabratus and susceptible to $R$. lauricola (Peña et al. 2012; Hughes et al. 2013). The attractiveness of California laurel and viñátigo to $X$. glabratus and their susceptibility to $R$. lauricola suggests that an importation event to their natural ranges could lead to laurel wilt outside the United States. The establishment of laurel wilt in new regions under natural conditions may be more difficult than suggested by artificial experimentation and is contingent on a number of factors including: (i) the arrival of $X$. glabratus to these new locations (naturally or human-assisted); (ii) the ability of $X$. glabratus to locate susceptible hosts; and (iii) the establishment of brood and successful reproduction within new host material.

\section{Disease Cycle and Symptom Development}

The disease cycle begins as female $X$. glabratus beetles disperse during late afternoon and early evening (Brar et al. 2012; Kendra et al. 2012a) in search of a viable host (Fig. 2). Guided by host volatiles and visual silhouettes, the female $X$. glabratus lands on and bores into the trunk and large stems of redbays (majority of boring holes occur below a stem height of $1.5 \mathrm{~m}$ ) and other members of the plant family Lauraceae (Fraedrich et al. 2008; Hanula et al. 2008; Niogret et al. 2011; Kendra et al. 2011, 2012a, 2013a, 2014a; Brar et al. 2012; Maner et al. 2012; Mayfield and Brownie 2013; Kuhns et al. 2014a). During its boring attempts, $X$. glabratus deposits $R$. lauricola from specialized conidia-bearing pouches (mycangia) near its mandibles into the sapwood, thus inoculating the tree. Spores of $R$. lauricola migrate passively through the xylem, causing the tree to produce gums and tyloses which impede water transport and cause the foliage to wilt (Inch et al. 2012; Inch and Ploetz 2012). Wilt can occur within a few weeks of inoculation, with preliminary symptoms appearing as dark olive-green, reddened, or browning leaves and drooping foliage in localized portions of the crown (Fig 3A). As symptoms progress, the wilt spreads to the rest of the canopy, resulting in complete crown wilt with marcescent brown leaves (Fig 3B, C). Within infected trees, removal of the bark will reveal xylem discoloration (brown/black streaking along the vessels) (Fig. 4). Disease progression from initial inoculation to complete crown wilt and tree death may take a few weeks to months, depending on environmental conditions. Observations suggest that as symptoms progress, affected trees often experience increased attacks from $X$. glabratus and other ambrosia beetle species. It is possible that plant-fungal interactions increase the release of volatiles attractive to X. glabratus females and those of other ambrosia beetle species. Also, the symbiotic fungi of some ambrosia beetles in 


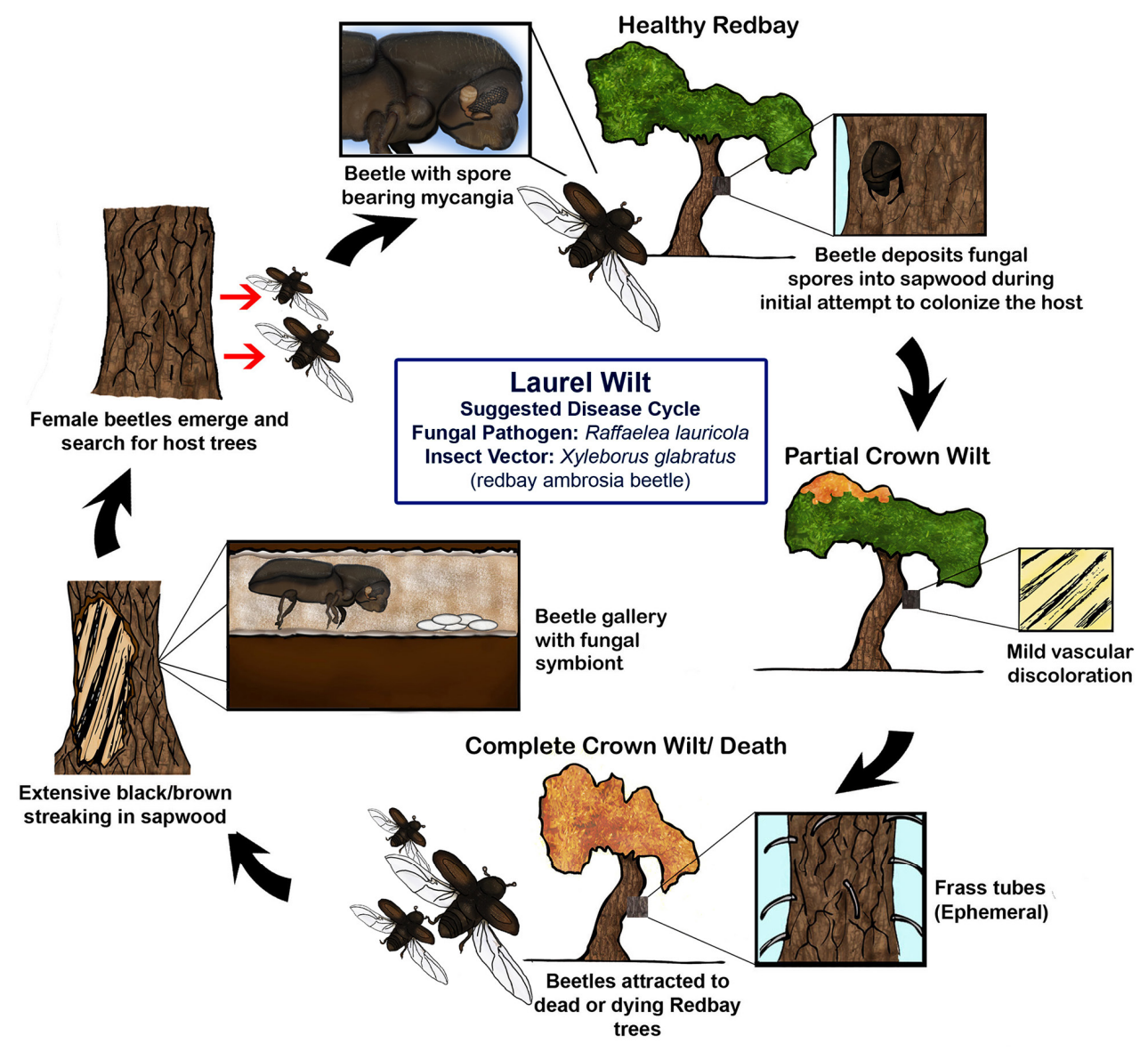

M. A. Hughes ${ }^{1}$, A. E. Mayfield ${ }^{2}$, J. Thomas and K. Olson

plantdochughes@gmail.com amayfield02@fs.fed.us jeffreythomasart.com kelseyo.com

University of Florida, School of Forest Resources and Conservation, Gainesville FL

${ }^{2}$ USDA Forest Service, Southern Research Station, Asheville NC

Last Revised 10/2014

\section{FIGURE 2}

Laurel wilt disease cycle in redbay trees (P. borbonia, P. palustris, and P. humilis).

Florida emit volatiles that attract their specific beetle species (Hulcr et al. 2011; Kuhns et al. 2014b).

As in the vascular wilt diseases of elm (Ulmus spp.) and oak (Quercus spp.) trees (caused by the fungi Ophiostoma novo-ulmi Brasier and Ceratocyctis fagacaearum (Bretz) Hunt, respectively), root graft transmission plays an important role in pathogen dissemination, and allows for infections to propagate without their insect vectors. For laurel wilt, root graft transmission of $R$. lauricola is a possibility, especially in hosts with connected root systems; however, studies have yet to confirm this avenue of spread. Due to the narrow spacing between avocado trees within a grove and anecdotal evidence of the movement of glyphosate via connected roots, it is probable that root grafting can occur among cultivated avocados (J. H. Crane, personal communication). Recently, root graft transmission appears to be contributing significantly to the local spread of laurel wilt in avocado groves due to the sequential appearance of symptomatic trees along rows and the lack of X. glabratus caught in traps within affected groves (R. C. Ploetz, personal communication). The connected root systems of sassafras and pondberry also may provide avenues for fungal movement, with observations suggesting that root graft transmission may already be occurring in sassafras (Cameron et al. 2010, 2012). Further experimentation is required to explore the role of underground pathogen movement in these hosts. 

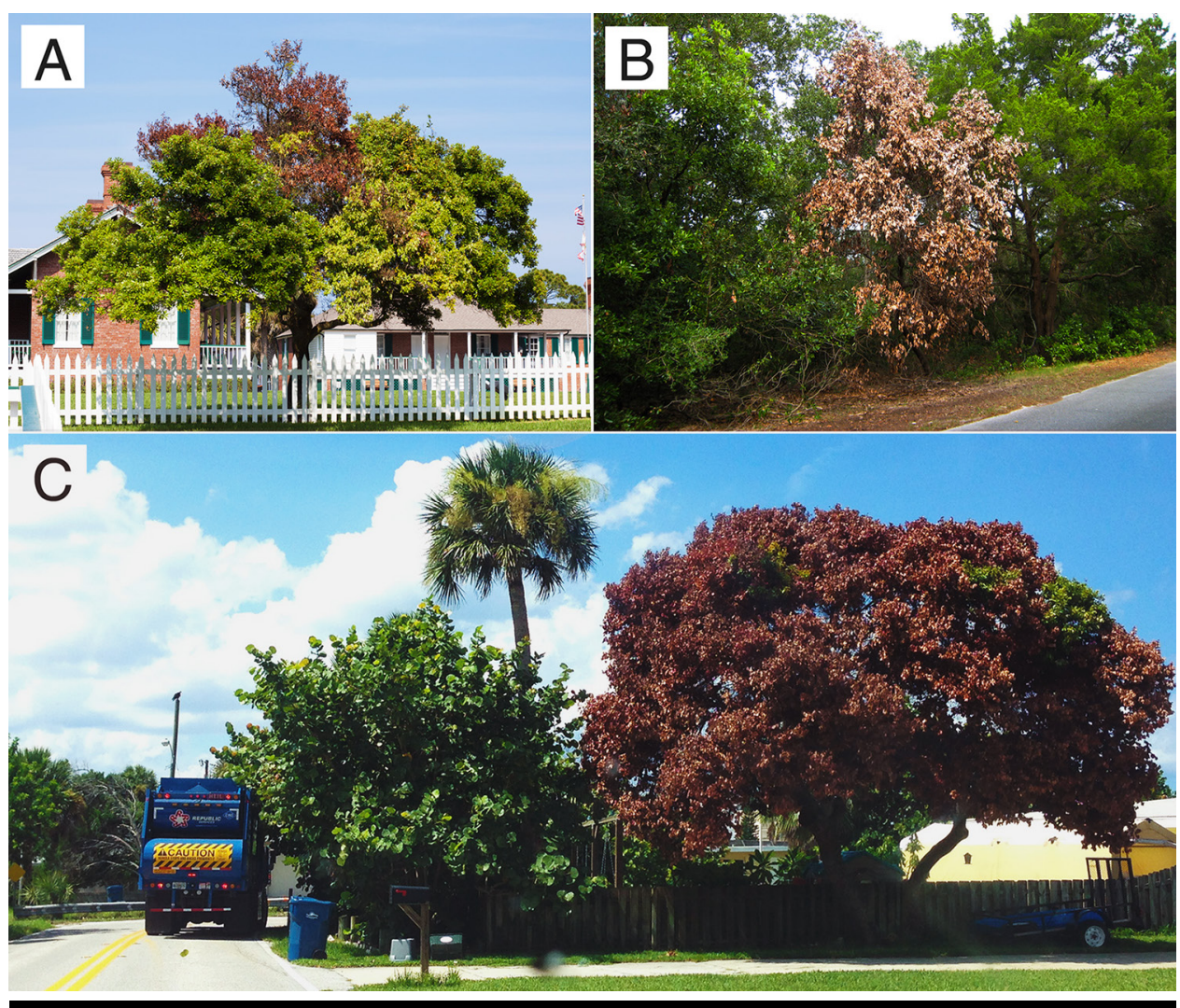

FIGURE 3

Laurel wilt external symptom development on redbay: (A) Browning of foliage and wilt of localized portions of the upper crown; (B and $\mathbf{C}$ ) complete crown wilt with attached leaves. Photos by Marc A. Hughes, University of Florida.
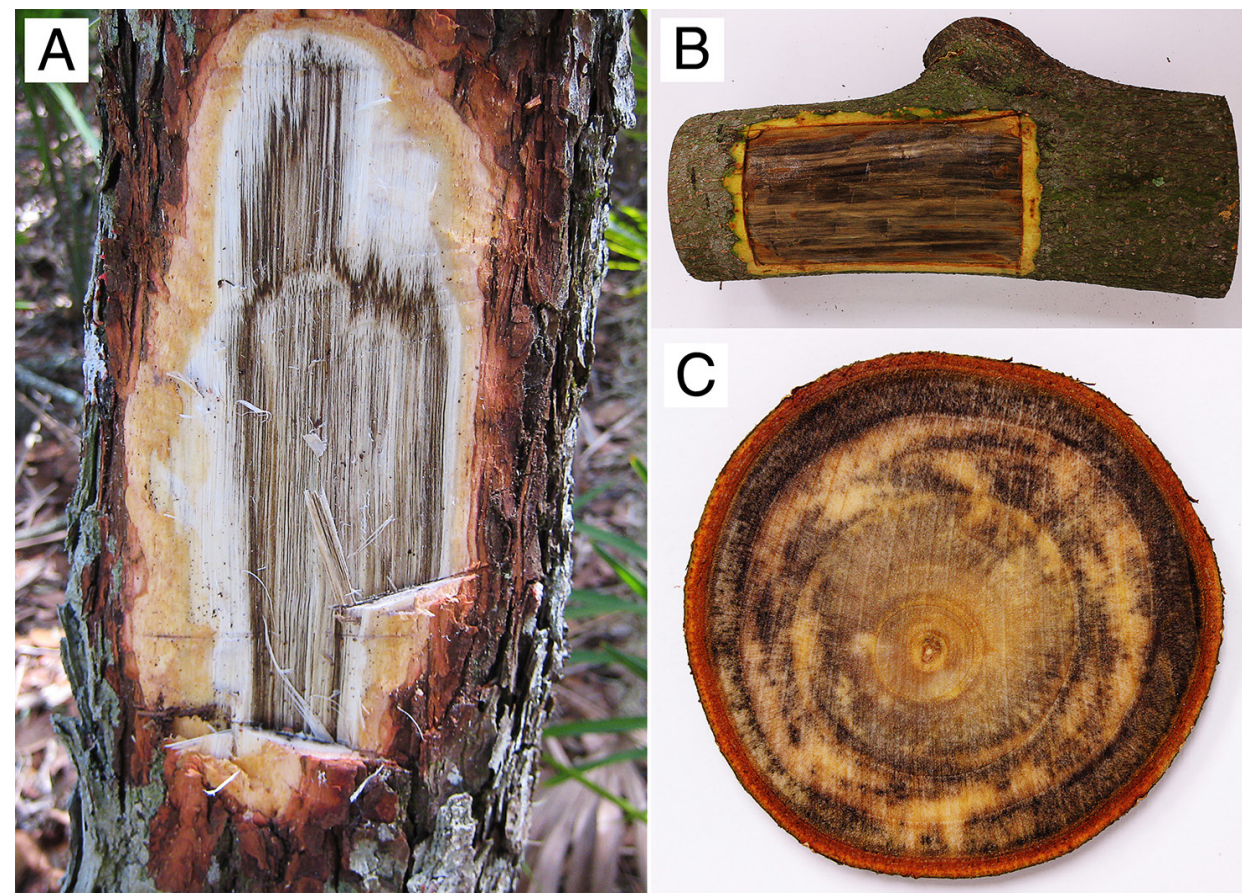

FIGURE 4

Sapwood discoloration in laurel wilt-affected redbay trees: (A and B) Longitudinal and (C) transverse sections. Photos by Marc A. Hughes, University of Florida. 
Evidence of ambrosia beetle attacks can be seen by the appearance of ephemeral tubes of boring dust ("frass tubes") that will hang from the trunk of attacked trees (Fig. 5A). Boring dust tubes are very delicate, and will eventually collapse due to wind or rain, leaving an accumulation of boring dust on the lower trunk or base of the tree (Fig. 5B). Females of $X$. glabratus lay eggs in the natal galleries in the xylem (Figs. 6 and 7A), and developing larvae and adults feed on the fungus that has colonized the gallery walls (Fig. 7B).

Xyleborus glabratus emergence can begin as early as 40 days after gallery formation in summer months (development is slower in colder months), with overlapping generations often occurring within the same tree (Hanula et al. 2008; Brar et al. 2013; Maner et al. 2013). Once mature, X. glabratus females emerge from their gallery systems and locate new hosts for the development of subsequent generations. Xyleborus glabratus can overwinter as all life stages, and therefore adults can disperse on warm days throughout the year (Hanula et al. 2008; 2011, Brar et al. 2012; Maner

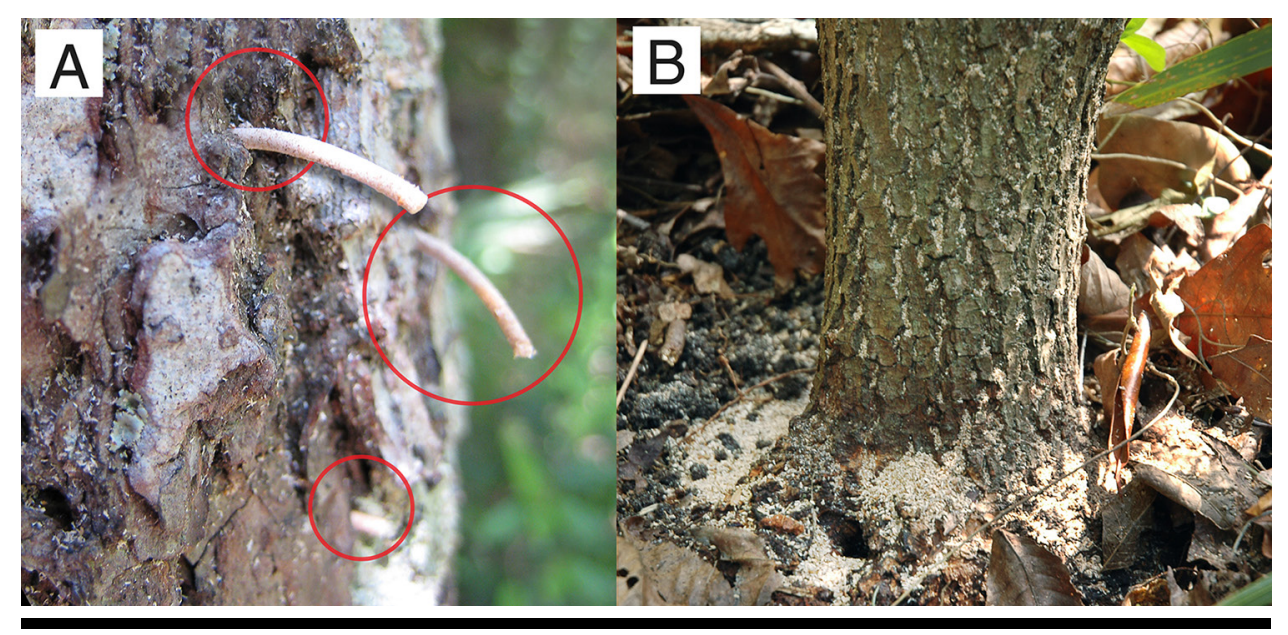

FIGURE 5

Evidence of ambrosia beetle boring activity. (A) Tubes of boring dust indicating recent entrance of ambrosia beetles into the trunk or stem. (B) Boring dust at the base of redbay tree indicating mass attack. Due to their delicate nature, dust tubes or the piles of dust at the base of trees can be carried away with rain or wind. Boring dust is a general symptom of any ambrosia beetle species attack and does not always indicate $X$. glabratus. Photos by Marc A. Hughes, University of Florida.

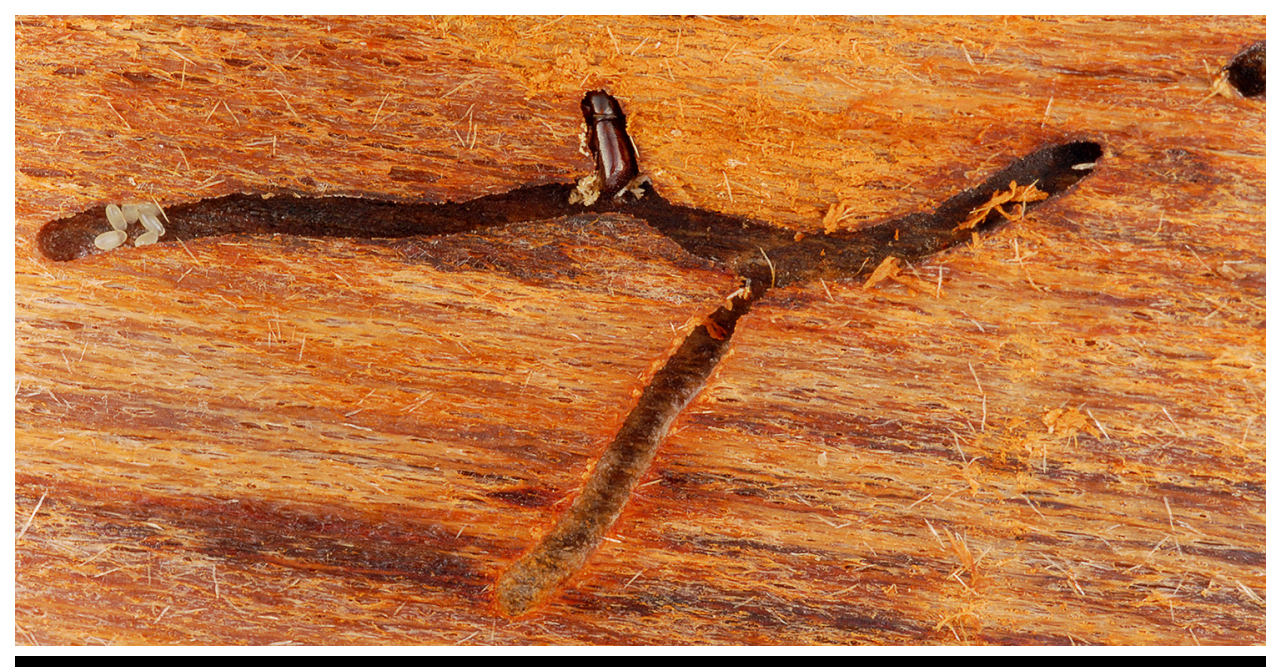

FIGURE 6

Redbay ambrosia beetle (Xyleborus glabratus) natal gallery in redbay tree with adult beetle and eggs. Photo by Lyle J. Buss, University of Florida. 


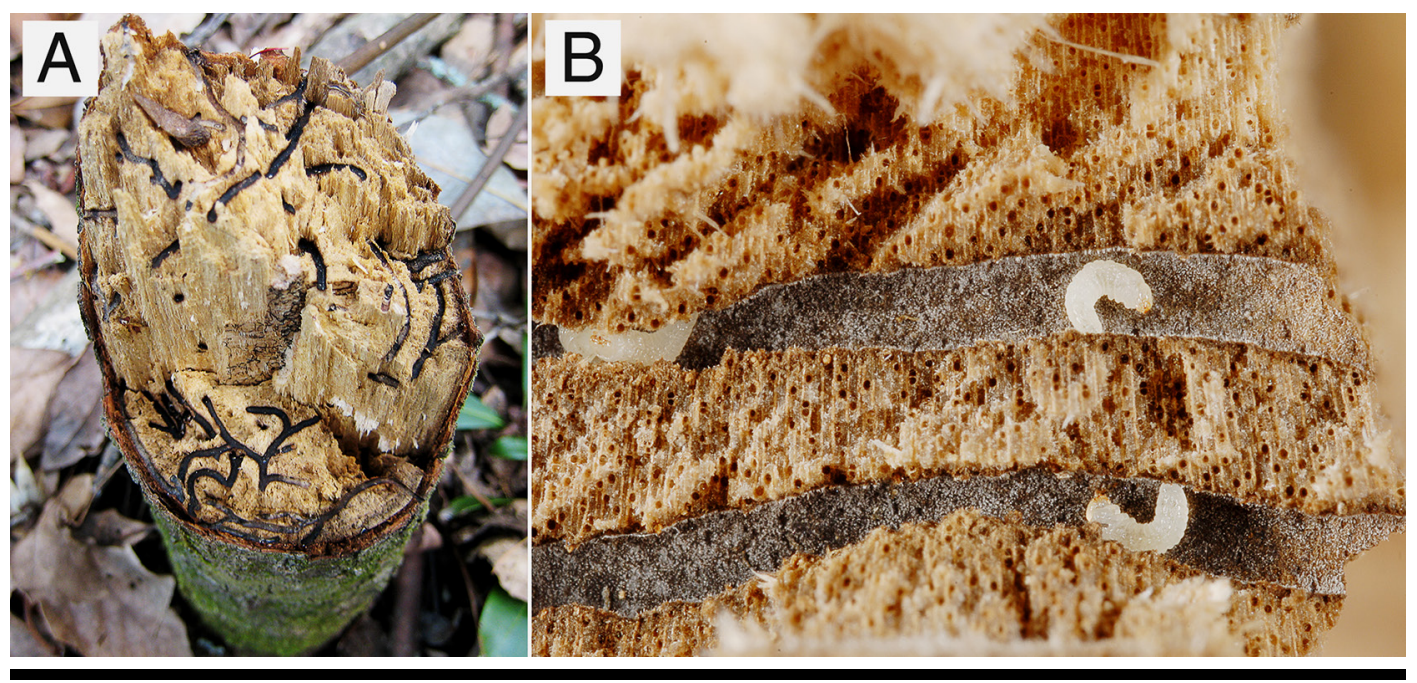

FIGURE 7

Redbay ambrosia beetle (Xyleborus glabratus) natal galleries in redbay tree: (A) Extensive gallery systems in transverse section; and (B) X. glabratus larvae feeding on symbiotic fungi that line gallery walls (white fuzzy material). Photos by Marc A. Hughes (A) and Lyle J. Buss (B), University of Florida.

et al. 2013); however, trap catches in Georgia and South Carolina suggest a peak flight season in September, with their population declining during the winter months (Hanula et al. 2008, 2011). In addition to September, Brar et al. (2012) noted a peak in flight in March to April in Florida, which suggests that variable environmental factors may affect their seasonal behavior. After attack, infested redbays can remain standing and their galleries can remain active for over a year (Brar et al. 2013; Maner et al. 2013). Raffaelea lauricola can still be recovered from trees for over a year after mortality until other decay organisms consume the tree, often leading to eventual breakage of the main stem (Spence et al. 2013) (Fig. 8).

Xyleborus glabratus has a haplo-diploid mating system, in which males develop from unfertilized eggs and possess only a single set of chromosomes (haploid), while the females have both their parents' genes (diploid). Males are rare compared to females (Maner et al. 2013 reported a 27:1 female to male ratio), are flightless, lack mycangia, and stay near or within the natal gallery for inbreeding with their siblings

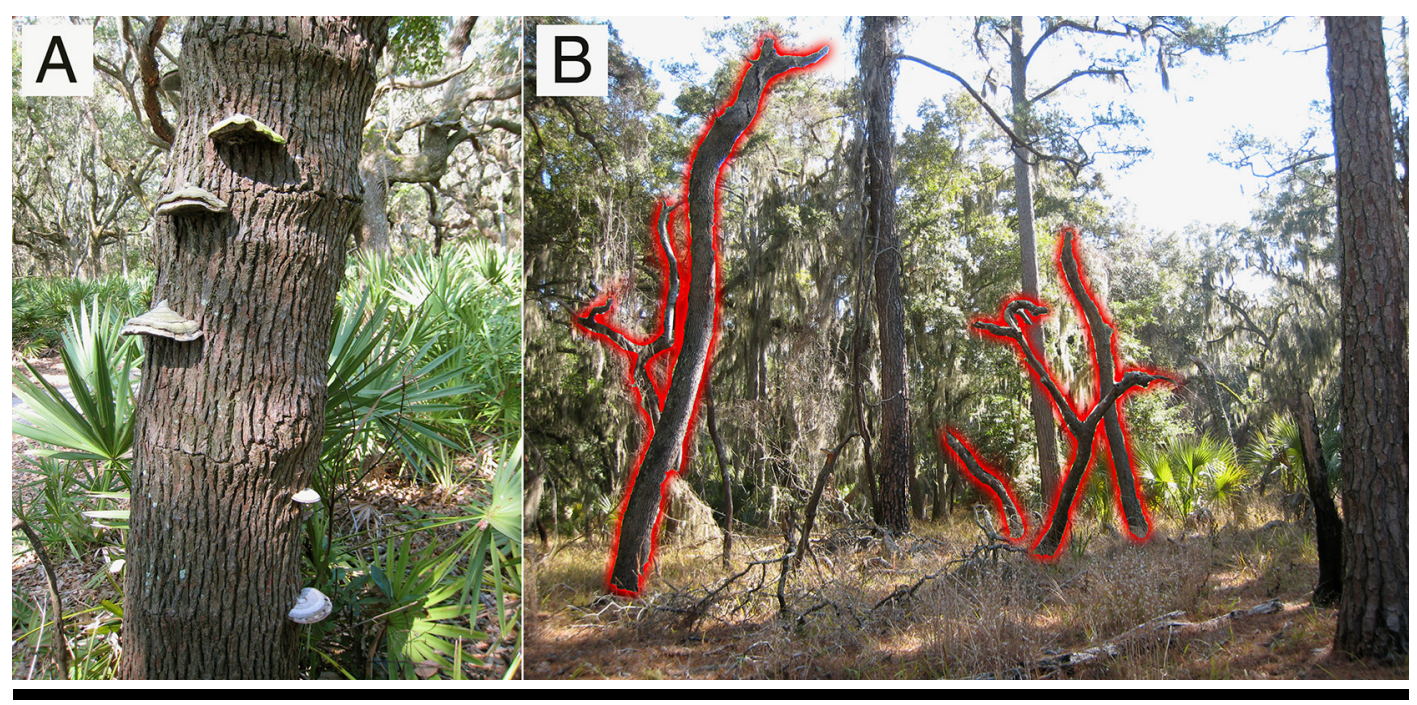

FIGURE 8

Fate of redbay trees after laurel wilt mortality: (A) Dead redbay tree colonized with decay fungi (in this case, Fomes fomentarius (L.) Fr.); and (B) breakage of redbay trunks (outlined in red) due to the loss of structural integrity from decay. Photos by Marc A. Hughes, University of Florida. 
to produce more females (Maner et al. 2013). Xyleborus glabratus females, with their ability to fly and transmit $R$. lauricola are the main drivers in the laurel wilt epidemic.

Studies on the host-seeking behavior of $X$. glabratus show that females are attracted to volatile terpenoids produced by host trees, including $\alpha$-copaene, $\alpha$ cubebene, $\alpha$-humulene, calamenene, and eucalyptol (Hanula and Sullivan 2008; Kendra et al. 2011, 2014a; Kuhns et al. 2014a), but not to ethanol, which is attractive to most other ambrosia beetle species (Hanula and Sullivan 2008; Kendra et al. 2014b). In sites new to laurel wilt infestation, large-diameter trees may be attacked first, indicating a preference of $X$. glabratus for larger stems; however, during an outbreak, all size classes can be affected simultaneously (Fraedrich et al. 2008; Kendra et al. 2013a; Mayfield and Brownie 2013; J. Eickwort, personal observation). In the absence of large redbays, X. glabratus populations can persist on smalldiameter stems at low levels (Maner et al. 2014).

Xyleborus glabratus females (Fig. 9A, B) are slender and cylindrical (2.1 to 2.4 $\mathrm{mm}$ long), and similar in size and shape to several other ambrosia beetle species. Characteristics useful for identifying adult females include their size which is smaller than most native ambrosia beetles, dark-brown to black color, nearly glabrous upper elytral surface with very little to no vestiture, and the distinctly angular elytral declivity. Males (Fig. 9C, D) are similar to females but are smaller (1.8 mm long), with a pronotum that is anteriorly flattened and has two short, flattened spines extending over the head capsule (Rabaglia et al. 2006).

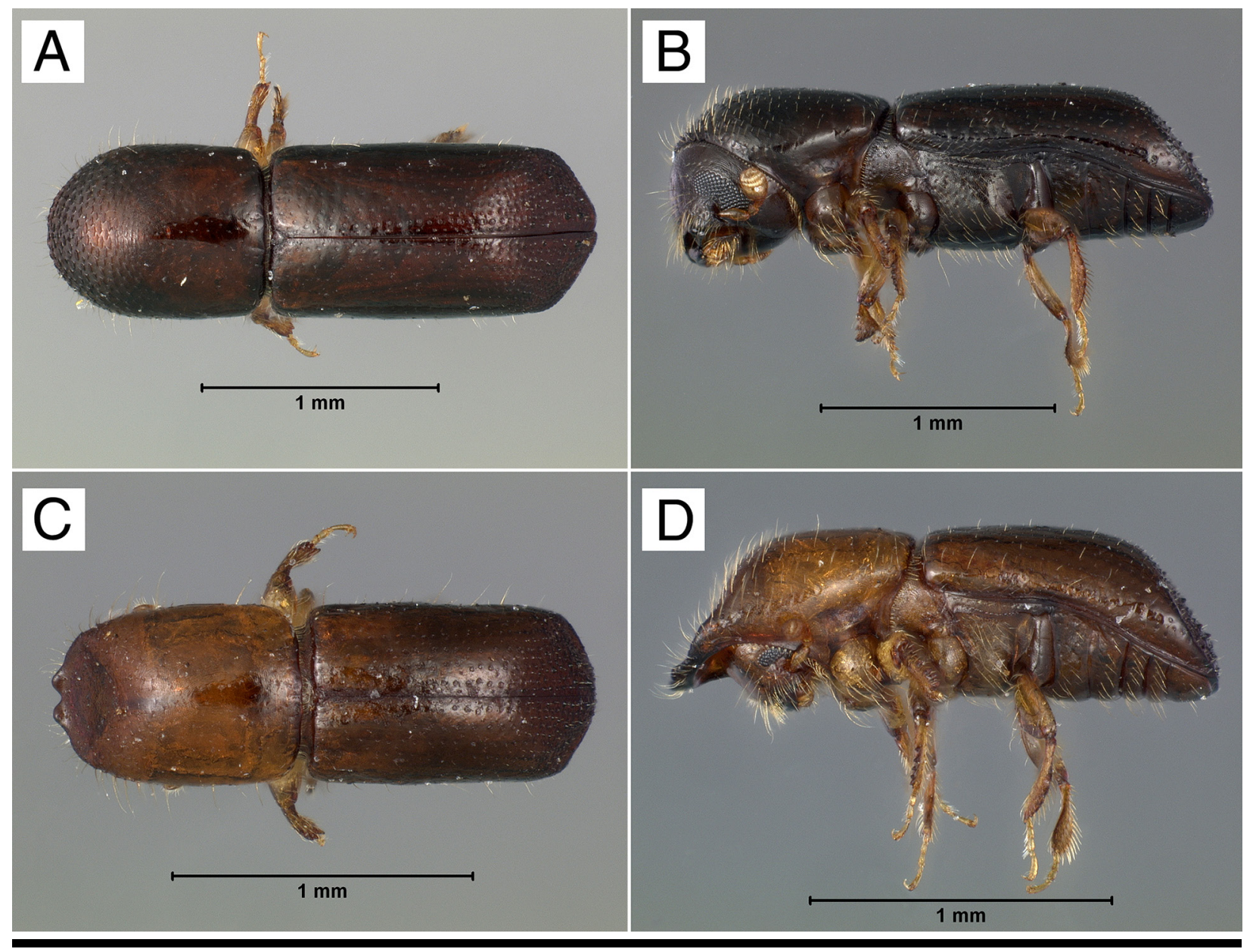

\section{FIGURE 9}

Redbay ambrosia beetle (Xyleborus glabratus): (A) Dorsal view of adult female; (B) lateral view of adult female; (C) Dorsal view of adult male; (D) Lateral view of adult male. Photos by Lyle J. Buss, University of Florida. 
Raffaelea lauricola is an asexual, dimorphic fungus that produces a yeast phase (budding cells) in the mycangium of $X$. glabratus, culture media (Fig. 10A), and in plant hosts, and mycelium on gallery walls and culture medium (Fig. 10B). Within galleries, the fungus produces tightly packed conidiophores (sporodochia) that are grazed on by the developing larvae and adults (Harrington et al. 2008). Up to six Raffaelea species have been isolated from X. glabratus; however, the role of species other than R. lauricola is unclear (Harrington et al. 2010). Their pathogenicity has been tested in swamp bay, but none other than $R$. lauricola have led to laurel wilt symptoms (T. Dreaden, personal communication). Raffaelea lauricola is the primary and most abundant symbiont of $X$. glabratus with most individuals harboring hundreds to thousands of spores within their mycangia (Harrington and Fraedrich 2010; Harrington et al. 2011; Carrillo et al. 2014). The fact that only 100 spores can cause wilt in swamp bay and avocado indicates that $R$. lauricola is highly virulent (Hughes et al. 2015).

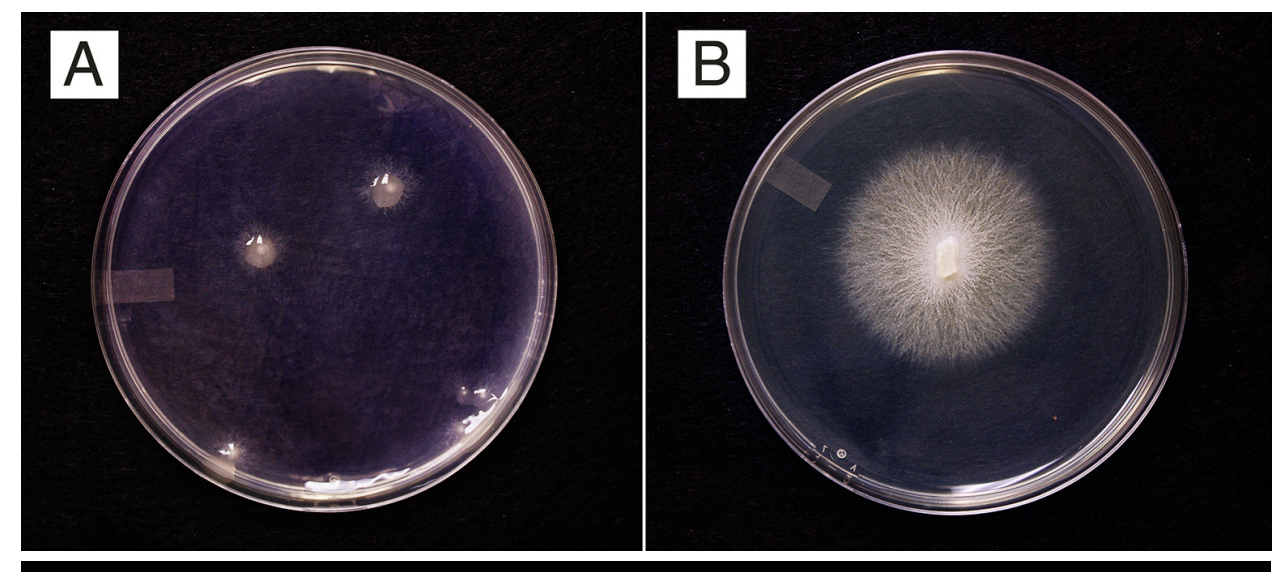

FIGURE 10

Raffealea lauricola on malt extract agar as a (A) yeast phase (5 days old), and (B) filamentous form (10 days old). Photos by Marc A. Hughes, University of Florida.

Raffaelea lauricola has been isolated from other ambrosia beetle species (Xyleborinus saxesenii Ratzeburg, Xylosandrus crassiusculus Motschulsky, Xyleborus ferrugineus Fabricius, Xyleborus affinis Eichhoff, Xyleborus volvulus Fabricius, Xyleborus bispinatus Eichhoff, and Xyleborinus gracilis Eichhoff) (Harrington and Fraedrich 2010; Harrington et al. 2011; Carrillo et al. 2014), but it is unclear whether these species can transmit the pathogen in nature and cause disease in otherwise healthy trees. Carrillo et al. (2014) documented that six ambrosia beetle species other than X. glabratus (above in bold) reared from laurel wilt-affected logs harbored $R$. lauricola. The pathogen was isolated from cohorts of each beetle species that were then used to challenge redbay (s.s) and avocado in no-choice tests. Raffaelea lauricola was recovered in avocados challenged with $X$. volvulus and $X$. ferrugineus, with $X$. volvulus able to induce laurel wilt in three of the five plants challenged. All ambrosia beetle species tested were able to transmit $R$. lauricola to redbay (s.s) and in varying degrees, cause laurel wilt symptoms. The probability of a beetle carrying $R$. lauricola was significantly lower in ambrosia beetles that acquired the pathogen via lateral transfer, and therefore a high attack density ( 40 beetles) was used in the no-choice tests (Carrillo et al. 2014). In general, the beetles found to carry $R$. lauricola did so at much lower levels [ 1 to 100 colony forming units (CFU) per beetle, depending on species] vs. X. glabratus $(\approx 2800 \mathrm{CFU}$ per beetle) (Carrillo et al. 2014). More research is needed to understand the role that other species of ambrosia beetles could play in the epidemiology of laurel wilt. 
The black twig borer (Xylosandrus compactus Eichhoff) is another ambrosia beetle whose damage can be misdiagnosed as the early stages of laurel wilt. Xylosandrus compactus (Fig. 11A) attacks small stems (typically less than $5 \mathrm{~cm}$ in diameter) on redbay and camphortree, as well as many other tree species throughout the southeastern United States (Dixon et al. 2011; Fraedrich et al. 2015). Damage by this beetle appears as the browning and wilting (flagging) of individual branches or stems (Fig. 11B). Attacks appear as a single pinhole on the stem (Fig. 11C), where the female constructs and lays eggs within the pith (Fig. 11D). The stem is hollowed and the surrounding xylem exhibits dark discoloration that will remain localized to within a few centimeters of the brood cavity (Dixon et al. 2011). Several differences exist between $X$. compactus damage and laurel wilt including: (i) branch and twig wilt associated with $X$. compactus is usually less severe and often scattered throughout the crown with intermittent green, healthy foliage, whereas laurel wilt initially affects larger crown sections but within days to months will often affect the entire crown; (ii) attacks on small-diameter stems with hollowed piths are suggestive of $X$. compactus, while the majority of the $X$. glabratus' attacks and boring will be on the lower trunk and large stems of the host: and (iii) vascular discoloration of the X. compactus will remain only on infected twigs and branches in close proximity to their entrance holes, while the xylem discoloration associated with laurel wilt is systemic and can be observed over large portions of the main stem and eventually the entire trunk of the tree. Due to their overlapping geographic and host ranges, one frequently observes
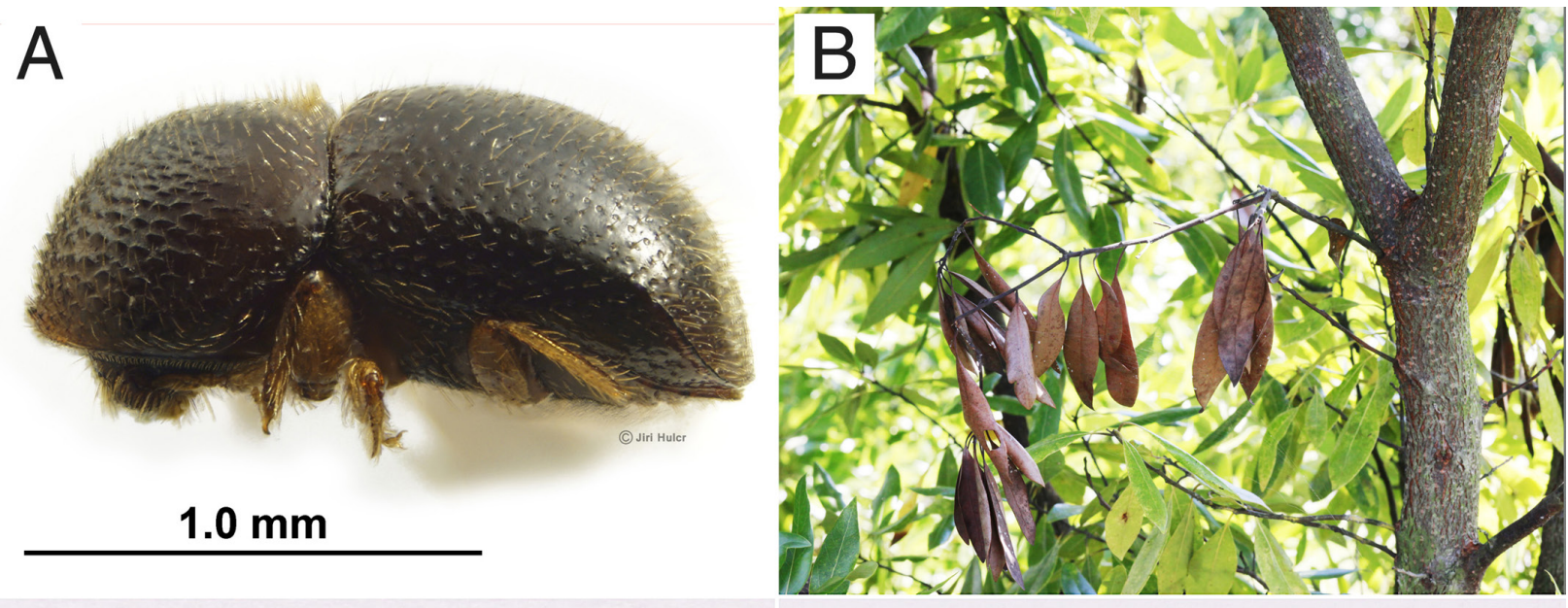

\section{C}
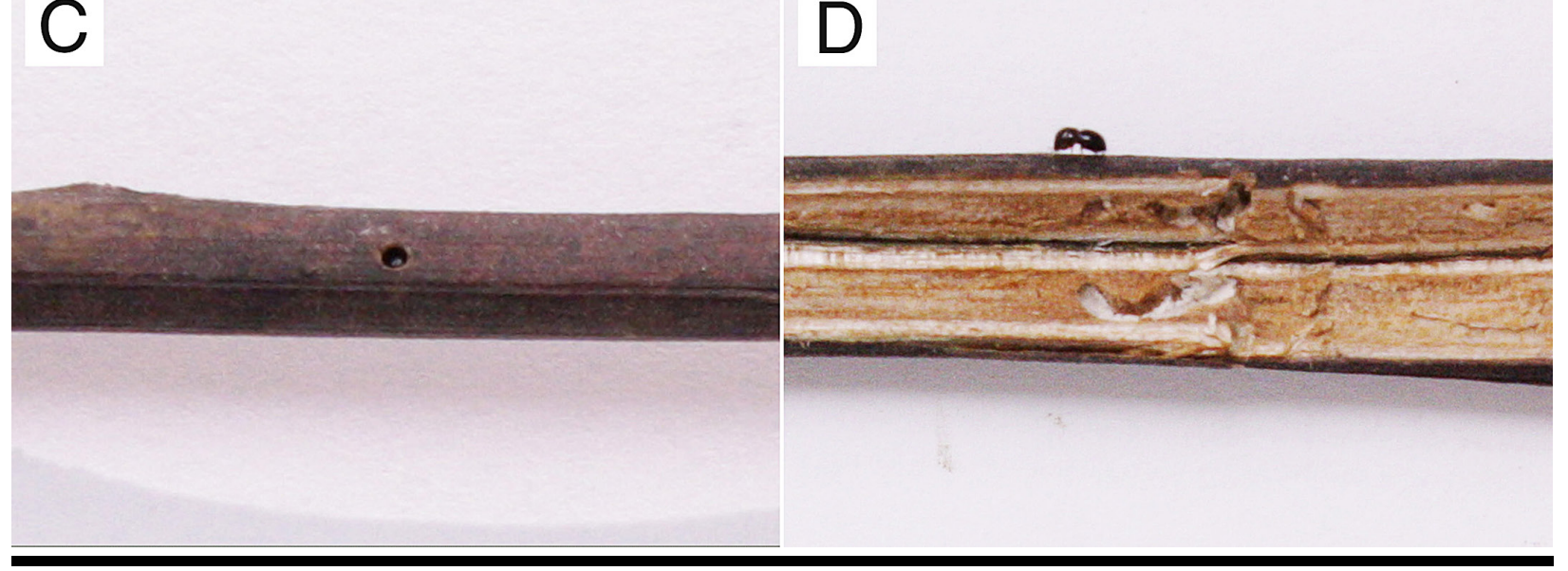

FIGURE 11

Black twig borer (Xylosandrus compactus): (A) Lateral view of adult female; (B) twig wilt (flagging) on redbay; (C) entrance hole; and (D) longitudinal section of affected twig showing a gallery within the pith of redbay and $X$. compactus. Photos by Jiri Hulcr (A) and Marc A. Hughes (B, C, D), University of Florida. 
damage by both $X$. glabratus and X. compactus; however, only laurel wilt is lethal to mature trees.

\section{Spread}

Xyleborus glabratus was initially detected in early monitoring traps near Port Wentworth, GA, in 2002 (Haack 2006). Laurel wilt was first recognized in Chatham County, GA, and in Beaufort and Jasper Counties, SC, in 2004. The disease has radiated outward along the Atlantic Coastal Plain and after 11 years has spread to 8 states (Alabama, Florida, Georgia, Louisiana, Mississippi, North Carolina, South Carolina, and Texas) (Fig. 12). Movement of the disease has mostly occurred to adjacent counties, but discontinuous jumps in distribution have also occurred (Fig. 12). The movement of laurel wilt to Volusia County, FL in 2008 was caused by the transport of infected logs by a resident for woodturning purposes (A. E. Mayfield, personal communication). The infestation of an area adjacent to a mulch plant in Brantley County, GA (2007), which was surrounded by unaffected counties, also suggests disease spread via movement of infected wood material (Cameron et al. 2008). Other geographic jumps in distribution appear to have occurred in Mississippi (2009), the Florida panhandle (2010), Alabama (2011), Louisiana (2014), and Texas (2015), suggesting that the movement of infested forest or wood products to new areas has occurred several times.

\section{Distribution of Counties with Laurel Wilt Disease* by year of Initial Detection}

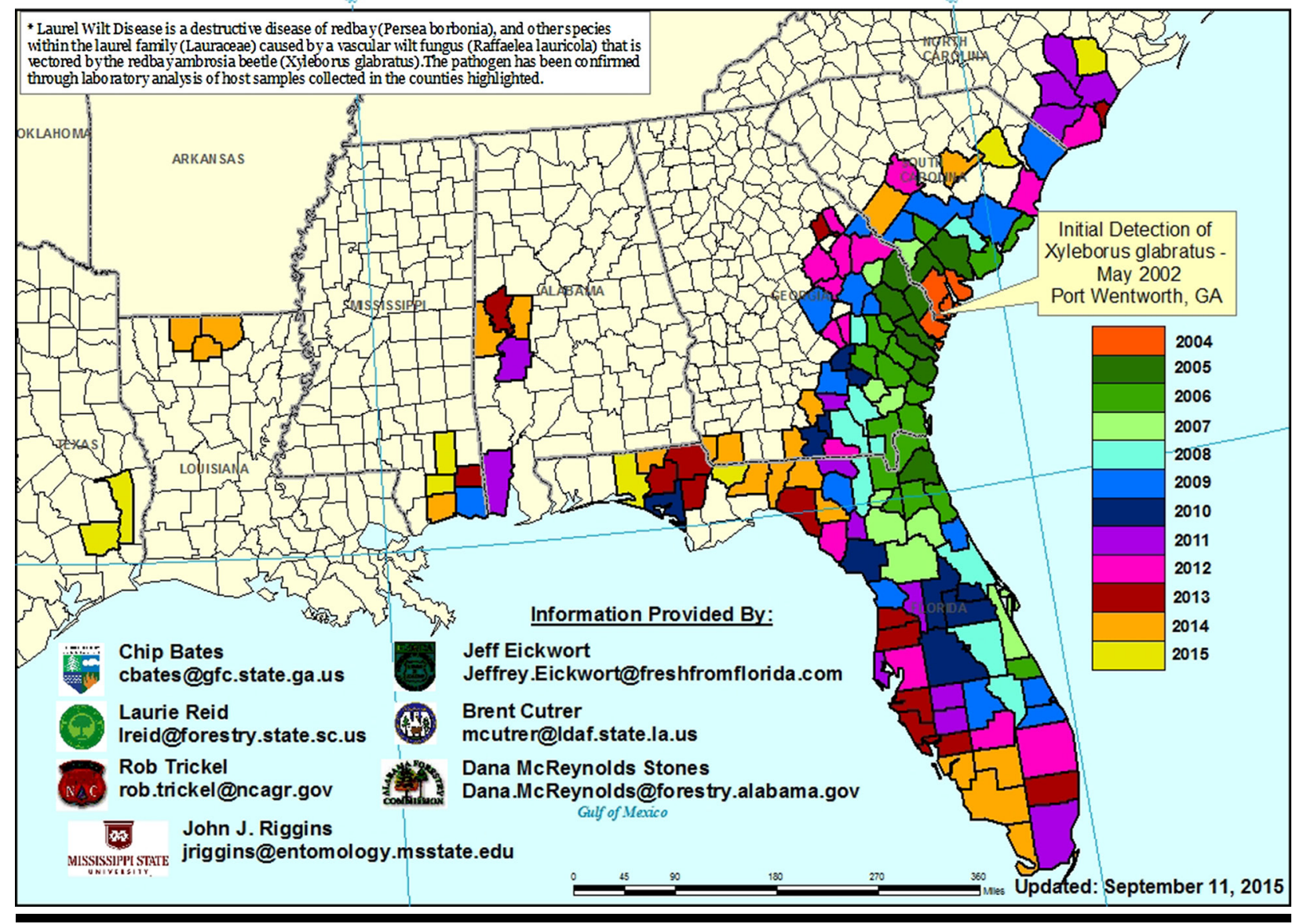

FIGURE 12

Laurel wilt distribution map. Color within a county indicates first year of confirmed laurel wilt infection. Photo by Chip Bates, Georgia Forestry Commission. 
In addition to vector spread by natural and human-assisted movement, anecdotal evidence suggests that root graft transmission may be occurring within sassafras and the commercial avocado groves. The importance of root graft transmission is less clear in redbay because of the lack of clearly observable infection foci in stands with these species, and because of the lack of empirical evidence of root grafting in redbay trees.

\section{MODELING OF DISEASE DISTRIBUTION AND EXPANSION}

An initial study to assess the threat of laurel wilt to eastern forests was conducted by Koch and Smith (2008). Their model utilized three factors: the geographic ranges and host densities of redbay (s.s) and sassafras; climate matching of X. glabratus' native range to that of the United States to infer the vector's potential geographic limits; and estimated rates of laurel wilt movement based on county incidence data. The resulting model predicted that laurel wilt movement would closely follow the documented geographic range of redbay (s.s) (coastal plain of the Atlantic and Gulf coasts), based on the assumptions that $X$. glabratus would not infest sassafras in the absence of nearby redbays (s.s) and that climatic constraints would limit its northern spread. However, laurel wilt disease and X. glabratus has been documented in sassafras stands in Georgia, Mississippi, Alabama, and Louisiana, where redbay is not present (Riggins et al. 2011; Cameron et al. 2012; Bates et al. 2013; C. Bates, personal communication). In addition, studies examining cold tolerance (supercooling point) showed that $X$. glabratus was able to withstand temperatures as low as $-24^{\circ} \mathrm{C}$; therefore, the spread model of Koch and Smith (2008) may have underestimated the ability of the beetle to move to colder northern areas where sassafras would be the main host (Formby et al. 2013). Little is known about the distance X. glabratus travels in dispersal flights. The mapping of laurel wilt spread among the Florida Everglades tree islands revealed a range of 1.0 to $11.8 \mathrm{~km}$ between neighboring symptomatic islands (Rodgers et al. 2014), suggesting that some long-distance flight (with the potential aid of wind currents) is possible, with an estimated spread rate up to $55 \mathrm{~km}$ per year (Koch and Smith, 2008).

\section{Monitoring and Detection}

\section{VECTOR DETECTION}

Monitoring and surveys have been conducted by state agencies with funding and additional support from federal agencies. Within Florida, updates on the movement of the disease have been accomplished by field detections and reports by the Florida Forest Service, the Division of Plant Industry, and county extension agents from the University of Florida. The Florida Cooperative Pest Survey (CAPS) has surveyed areas in Miami-Dade County in order to delineate areas of $X$. glabratus infestation by scouting host-dense natural areas and by the deployment of Lindgren funnel traps baited with manuka oil lures, with special attention to the avocado-production areas (Whilby et al. 2012). Ongoing surveys by the Alabama, Georgia, South Carolina, and Mississippi Forestry Commissions, Mississippi State University, the North Carolina Forest Service, and the Louisiana Department of Agriculture and Forestry are being conducted based on vector trapping and field scouting of infected sites to estimate the impacts of laurel wilt disease (Cameron et al. 2008, 2010; R. Trickel, B. Cutrer, and D. Stone, personal communications).

Early trapping attempts revealed that $X$. glabratus was not attracted to ethanol lures like most ambrosia beetle species, which prefer stressed and dying trees (Hanula and Sullivan 2008; Kendra et al. 2012b). Cut bolts or logs from host trees are attractive to $X$. glabratus and can be used to lure and collect live beetles (Hanula et al. 2008; Kendra et al. 2012b). However, due to the dwindling amount of fresh host material in areas affected by laurel wilt, this method was not feasible for long-term 
monitoring efforts. Collection of volatiles from host-tree wood revealed several chemical constituents as possible attractants, predominantly the sesquiterpene $\alpha$ copaene (Hanula and Sullivan 2008; Niogret et al. 2011; Kendra et al. 2011, 2013b). Since $\alpha$-copaene is expensive and difficult to synthesize, several essential oils high in $\alpha$-copaene were evaluated as field lures. Initial research identified manuka oil (an extract from Leptospermum scoparium J.R. Forst. \& G. Forst.) and phoebe oil (from Ocotea porosa (Nees \& Mart.) Barroso) as attractive baits for X. glabratus (Hanula and Sullivan 2008). With the commercial availability of manuka oil lures, various agencies and researchers adopted this product in conjunction with a Lindgren funnel trap as the standard detection system. Unfortunately, manuka oil lures have been shown to be sub-optimal due to their: (i) limited window of attractiveness observed in field trials (as little as 2 weeks); (ii) variability in the efficacy of lures manufactured in different years; and (iii) attraction of various non-target species (Kendra et al. 2011, 2012c; Brar et al. 2012; Hanula et al. 2013). Subsequent research identified cubeb oil (from Piper cubeba L.f.) as a new attractant for X. glabratus (Kendra et al. 2013a), and a commercially available bubble lure containing distilled cubeb oil was shown to capture significantly more beetles than the manuka oil lure and to last at least 12 weeks (Hanula et al. 2013; Kendra et al. 2014b, 2015a). To elucidate the primary attractants of $X$. glabratus, fractional distillation was used to separate cubeb oil into 17 fractions, which were then tested separately in lab bioassays (Kendra et al. 2015b). Fractions highest in $\alpha$-copaene were most attractive, confirming a dominant role for this sesquiterpene, which led to the development of a prototype bubble lure containing $50 \%$ (-)- $\alpha$-copaene. In initial field trials (Kendra et al. 2015b), the copaene lures performed much better than commercial cubeb lures, indicating that more sensitive detection of $X$. glabratus should be available in the near future.

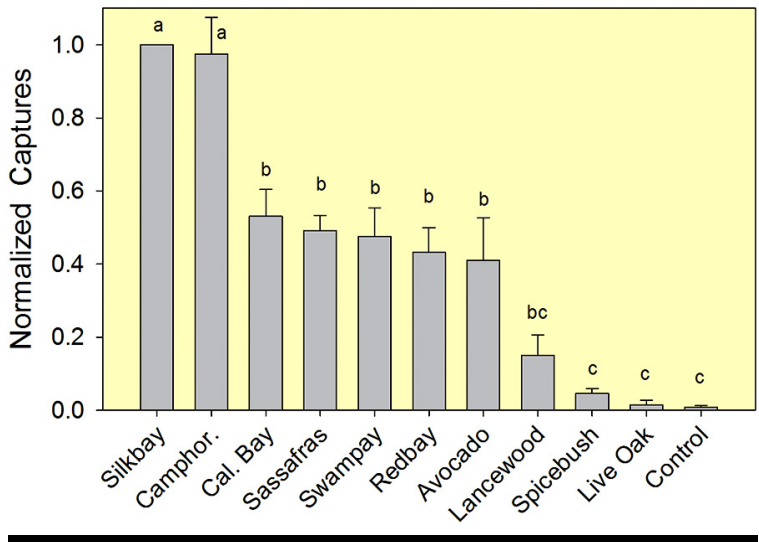

FIGURE 13

Relative attraction of $X$. glabratus to nine species of Lauraceae, as indicated by captures in sticky traps baited with wood bolts. Treatments also included live oak (Q. virginiana, a non-host) and an un-baited control trap. Graph presents composite results from two replicated field tests; therefore, captures were normalized by converting to percentages relative to silk bay ( $P$. humilis), the most attractive species, used as a positive control in each test. (Adapted from Kendra et al. 2014a).
A recent comparative study (Kendra et al. 2014a) evaluated nine species within the Lauraceae in terms of terpenoid emissions and relative attraction of $X$. glabratus (Fig. 13). In addition to $\alpha$-copaene, three other sesquiterpenes were positively correlated with attraction: $\alpha$ cubebene, $\alpha$-humulene, and calamenene. Interestingly, California laurel, a species attractive to female $X$. glabratus (Mayfield et al. 2013) and susceptible to laurel wilt (Fraedrich 2008), was found to have low sesquiterpene content and high emissions of eucalyptol, a monoterpene ether. Eucalyptol alone, in high doses, has also been shown to attract X. glabratus (Kuhns et al. 2014a). This information suggests that multiple chemical cues may contribute to the location of host Lauraceae by $X$. glabratus. Those cues also include attractive volatiles from the leaves of redbay (s.s) and swamp bay (Martini et al. 2015) and the fungal symbiont (Hulcr et al. 2011). In addition, a combination of fungal- and host-based odors has been shown to capture more $X$. glabratus than host odors alone (Kuhns et al. 2014b); therefore, further research is needed to evaluate efficacy of multi-component lures (e.g., $\alpha$-copaene + eucalyptol + fungal odors).

\section{DIAGNOSIS OF THE PATHOGEN}

For use in plant diagnostic laboratories, the National Plant Diagnostic Network (NPDN) developed a standard operating procedure for the diagnosis and identification of $R$. lauricola and X. glabratus (Harmon and Brown 2011; Harmon 2014). This report documents the steps for proper packing and shipment of samples to diagnostic 
labs, descriptions of laurel wilt symptoms, X. glabratus identification, fungal isolation instructions, DNA extraction methods, and PCR identification protocols. The first step in a laurel wilt diagnosis is the isolation of $R$. lauricola from host wood, which can be accomplished by surface disinfestation of discolored wood chips by dipping into $95 \%$ ethanol and flaming or by dipping in a $10 \%$ bleach solution, rinsing in sterile water, and then placing on CSMA media (cycloheximide-streptomycin malt agar) (Harrington 1981; Fraedrich et al. 2008; Harmon 2014). Diagnostic morphological characteristics can be obtained from Harrington et al. (2008) and Harmon (2014). After isolation onto media, DNA extraction and PCR amplification is conducted for positive confirmation. Previous to 2014, molecular detection relied on the primers developed for the small subunit (SSU, 18S) of the ribosomal DNA (rDNA), the primers LWD1/ LWD3 for standard PCR, and LWD3/LWD4 for real-time/quantative PCR (qPCR) (Harmon and Brown 2011; Dreaden et al. 2014; Harmon 2014). However, in 2009, an undescribed Raffaelea species (isolate PL1004) was isolated from an avocado tree suspected to have laurel wilt. It was $99 \%$ similar in SSU sequence to $R$. lauricola, but not pathogenic (Dreaden et al. 2014; Harmon 2014; R. C. Ploetz and T. Dreaden, unpublished). The qPCR primers LWD3/LWD4, are specific to $R$. lauricola and Raffaelea brunnea T.C. Harr. (an ambrosial symbiont of the oak ambrosia beetle, Monarthrum spp.); however, late in the amplification process other Raffealea species can also be amplified, but the method has some experimental utility (Dreaden et al. 2014). Thus, these primers were abandoned for diagnostic purposes.

To improve the detection of $R$. lauricola and limit the possibility of non-specific amplification of unknown species, a PCR assay was developed with two taxonspecific simple sequence repeat (SSR) loci. It is compatible with standard and qPCR methodologies and has a low detection limit $(0.1 \mathrm{ng})$ when DNA is extracted from a fungal culture (Dreaden at al. 2014; Harmon 2014). This detection method is now being used by diagnostic labs at the University of Florida Plant Diagnostic Center and recommended within their standard operating procedure (Harmon 2014).

Since taxon-specific primers did not exist before Dreaden et al. (2014), positive confirmation of $R$. lauricola would often rely on the sequence analysis of the large subunit (LSU, 28S) and/or small subunit (SSU, 18S) of the rDNA. Unlike the majority of fungal species, amplification and sequencing of the Internal Transcribed Spacer (ITS) region (and sometimes the LSU) of the rDNA is problematic for $R$. lauricola due to the presence of high GC content and the formation of secondary structures (Fraedrich et al. 2008; Jeyaprakash et al. 2014). Jeyaprakash et al. (2014) established a Taqman qPCR probe based on the LSU rDNA region where PL1004 and $R$. lauricola have $100 \%$ sequence homology, implying the method will detect PL1004 and $R$. lauricola equally well, possibly resulting in false positives (T. Dreaden, personal communication). This method was found to successfully amplify the pathogen from cultures and/or infected wood samples and is currently in use for detection by the Florida Division of Plant Industry (along with confirmatory pathogenicity testing for avocado samples) (Jeyaprakash et al. 2014). The authors also described a modified PCR protocol that allows for amplification and sequencing of a portion of the LSU and ITS regions (Jeyaprakash et al. 2014).

\section{POPULATION GENETICS}

Studies on the genetic diversity of $X$. glabratus and $R$. lauricola populations are in progress.

\section{Response}

As a new and emerging threat to forests of the United States, the response to this disease is under the supervision of the United States Department of Agriculture 
Animal and Plant Health Inspection Station (USDA-APHIS-PPQ), delegated by the Secretary of Agriculture under the Plant Protection Act of 2000.

Xyleborus glabratus was first detected in USDA Forest Service Early Detection \& Rapid Response (EDRR) Pilot Project traps in Port Wentworth, GA, in 2002. This trapping initiative was conducted by the USDA Forest Service to monitor new and invasive species that may be entering the country through our ports, and ethanol lures were typically used to trap beetles. Initially, three female $X$. glabratus beetles were captured in proximity to warehouses near Port Wentworth. To assess the extent of the $X$. glabratus population within the area, additional traps were placed in coordination with APHIS. No other females were caught and thus beetles were suspected to have emerged directly from solid wood packing material (a common pathway for woodboring insect introductions) and not from local infested trees (Mayfield et al. 2009). Although ethanol lures are effective for trapping most ambrosia beetles, it is now known that these lures are not effective for trapping $X$. glabratus and initial populations may have been underestimated.

During 2003-2004, mortality of redbay (s.s) trees was observed at Hilton Head Island, SC, and neighboring localities in South Carolina and Georgia. Subsequent examinations revealed a common symptomology among wilted trees that included: rapid crown wilt; vascular discoloration; evidence of ambrosia beetle attack; and eventually the consistent presence of $X$. glabratus and a new Raffealea associated with the discolored xylem of affected trees. Researchers determined that the causal agent of the disease was a species of Raffaelea, later named Raffaelea lauricola (Harrington et al. 2008) and was transmitted by X. glabratus, and the new disease was named laurel wilt (Fraedrich et al. 2008).

Two symposia (2007 and 2009) were hosted by the Georgia Forestry Commission and the USDA Forest Service, Forest Health Protection program with participants from the USDA Forest Service, universities, state agencies, and other interested parties to exchange preliminary information on disease distribution, monitoring, biology, and management. In 2015, a similarly themed conference was hosted by the University of Florida. An ad hoc Laurel Wilt Working Group was formed in 2007 among university, state, and federal scientists to facilitate gathering and dissemination of information on laurel wilt disease on forest hosts and discuss research needs; it is no longer active. A separate Laurel Wilt Working Group that focuses on avocado management is still active.

A laurel wilt website was established by the USDA Forest Service, Region 8 Forest Health Protection to inform researchers and the public about laurel wilt distribution, biology, management, contacts, and advances in research; however, this website is no longer operational. State forestry agencies (Alabama, Florida, Georgia, Mississippi, North Carolina, South Carolina, and Texas) and universities have created webpages about laurel wilt to inform the public on the various aspects of the disease and its management, as well as information on what to do if laurel wilt is suspected in the landscape. A collaborative, multi-organizational website was created for Texas residents to report possible new laurel wilt infestations. A campaign for laurel wilt of avocado, "Save the Guac," has also been launched to inform residents of dangers that this disease poses to the Florida avocado industry, along with a hotline to notify agents of possible laurel wilt sightings. The web addresses and other information on these websites can be found below in Web Resources.

Additionally, extensive scientific research has been conducted by various federal, state, and university scientists into the various facets of laurel wilt, including: ecosystem impacts; host propagation and resistance; chemical management of the disease and vector; disease biology, epidemiology, and expansions of host range; vector biology and chemical ecology; disease transmission; and many other aspects. The research resulted in management guidelines that are provided below. 
A preventative fungicidal treatment of high-value trees with propiconazole via macro infusion is currently the best method of protection; however, longevity is limited and with re-application needed every 1 to 1.5 years on average, in addition applications should be done professionally (Mayfield et al. 2008b; D. Spence, personal communication). Management guidelines are provided within the appropriate state/federal agency and extension websites. In general, it is suggested that trees with laurel wilt be taken down and chipped to limit the reproduction of the vector (Spence et al. 2013). Tree stumps are known to support X. glabratus reproduction and should be removed or ground down (J. Hanula, personal communication). If chipping is not possible, felled trees or logs should be left on site and covered with plastic or buried, if feasible. If laurel wilt is widespread within an area, logs and other infested woody material can be taken to a county dump where trees can be buried. Longdistance transport of this material is discouraged as it aids in the expansion of disease to new areas (Crane and Smith 2010).

\section{Permits and Regulatory Issues}

As stated on the USDA-APHIS webpage (see Web Resources):

USDA regulates the importation and interstate movement of plant pathogens by requiring permits (codified at 7 CFR 330.200 to 330.212). Plant pathogens also include non-genetically engineered infectious substances, which can directly or indirectly injure, cause disease, or damage in any plants, plant parts, or plant products. If the organism is imported on/in host material, no separate permit is required if the host material is not intended for propagation.

Dontmovefirewood.org details specific state regulations for the transit of firewood (see Web Resources). Encouragement for the use of locally harvested and bought firewood is universal among host states, with a transport of less than 50 miles recommended (10 miles ideal). Among states currently affected by laurel wilt, no specific regulations exist for Alabama, Louisiana, Mississippi, South Carolina, and Texas, although the movement of firewood out of quarantined states into these states is prohibited to control other exotic organisms such as red imported fire ant. For the states of Georgia and North Carolina, general regulations exist limiting the movement of firewood for specific counties and parks (see dontmovefirewood.org for details). Although regulatory actions have been taken to restrict the movement of wood that could spread other pests, no such actions have been taken to restrict the movement of $X$. glabratus and $R$. lauricola into new areas. Although these regulations do not apply to laurel wilt, any actions to lessen the movement of firewood or unprocessed wood products will, by default, aid in suppressing laurel wilt spread. The Florida Department of Agriculture and Consumer Services, Division of Plant Industry, enacted Rule 5B-65 (the Firewood and Unprocessed Wood Products rule) in 2010 to suppress the movement of laurel wilt-infested wood and wood products (see Web Resources). In brief, movement of regulated articles requires permits and certificates of inspections (depending on classification of commercial or non-commercial); firewood and unprocessed wood products are exempt if remaining within 50 miles of point of origin; and, for the protection of the avocado production areas, no firewood produced outside Miami-Dade County may enter unless certified.

\section{Cultural, Economic and Ecological Impacts}

\section{CULTURAL IMPACTS}

The Lauraceae contains several plant species that play a central role in the medicinal and cultural activities of American Indian communities across North America; these include sassafras, California laurel, redbay (s.s), and swamp bay. The 
Seminole and Miccosukee Tribes in Florida depend on redbay (s.s) and swamp bay for more than $90 \%$ of traditional medicinal preparations and the plants are used in a majority of significant cultural celebrations and ceremonies (Snow and Stans 2001). Extinction of redbay (s.s) and/or swamp bay would lead to the loss of its use by Seminole and Miccosukee communities, who have been dependent on this ingredient for generations. The tribes are concerned about this loss of cultural heritage (Chief Billie 2014) and tribal foresters are looking into ways to mitigate the loss. Propagation of redbay (s.s) and swamp bay trees from tribal lands is underway at the University of Florida and new studies are planned to evaluate the use of coppice regeneration to maintain plants for cultural uses (J. Smith, personal communication).

\section{ECONOMIC IMPACTS}

Redbay and other forest host species are generally not considered economically important; however, the avocado industry is in peril and is covered within its own USDA Recovery Plan (Ploetz et al. 2011a). However, due to the abundance of redbay and other native host trees within certain regions, their mortality and management could potentially have economic impacts, including:

- the cost of tree removal and disposal for residential homes, state and city parks, roadways, municipalities, and other instances where trees cannot be left standing on-site;

- loss of residential property value for homeowners from the loss of large, aesthetically pleasing trees, and/or the costs for replanting where is it mandated by statutes;

- increase in administrative costs for state and local governments for materials and time associated with educating the public about laurel wilt and monitoring its spread;

- possible loss of revenue for businesses that deal with firewood, mulches, and other unprocessed wood products due to increased regulation in movement and loss of viable wood supply due to the disease;

- loss of revenue for the nursery industry that deals in the sale and propagation of these lauraceous species due to possible stop on sale orders from material deemed infected and from the loss of potential sales from homeowners and agencies that choose not to purchase these species for fear of laurel wilt;

- fire hazards from increased fuel loads due to dead trees within natural areas; and

- possible temporary restricted access due to hazardous decomposing trees killed by laurel wilt.

\section{ECOLOGICAL IMPACTS}

Laurel wilt has decimated members of the Lauraceae in the southeastern United States. Among the native laurels, none have been more affected than the aromatic native trees redbay (s.s) and swamp bay. Laurel wilt causes rapid mortality of redbay (s.s) and often relatively few trees over $2.5 \mathrm{~cm}$ in diameter survive a few years after infestation (Fraedrich et al. 2008; Shields et al. 2011; Evans et al. 2013; Spiegel and Leege 2013). The sudden and substantial mortality of a once abundant tree has changed the species composition in affected areas, with redbay (s.s) being replaced by other tree species (Goldberg and Heine 2009; Gramling 2010; Shields et al. 2011; Evans et al. 2013; Spiegel and Leege 2013). Behavioral studies show that X. glabratus prefers to attack large-diameter trees, but all size classes are susceptible to attack (Fraedrich et al 2008; Cameron et al. 2012; Maner et al. 2012, 2014; Kendra et al. 2013a; Mayfield and Brownie 2013). Trapping studies have found that after the initial wave of laurel wilt mortality, $X$. glabratus populations decline dramatically as suitable host materials become scarce (Hanula et al. 2008; Cameron et al. 2012; Maner et al. 2014). However, in the absence of large host trees, X. glabratus persists in smaller- 
diameter hosts $(>3.0 \mathrm{~cm})$ and as stump-sprouts mature they will likely be re-attacked to support newer generations (Cameron et al. 2012; Maner et al. 2014). Redbays resprout readily from the base and this mechanism allows for some persistence of the trees, with follow-up monitoring of these basal sprouts suggesting good rates of survivability thus far (S. Cameron, S. W. Fraedrich, and J. Eickwort, personal observations). However, a study by Evans et al. (2013) tracked the fate of re-sprouts within St. Catherines Island (GA) and found $78 \%$ mortality among basal sprouts, likely due to laurel wilt and deer browsing, suggesting that these sprouts may not be a viable method to maintain redbay (s.s) populations in unique island habitats with high deer populations.

Sassafras is also susceptible to laurel wilt and capable of supporting broods of $X$. glabratus (Riggins et al. 2011; Cameron et al. 2010). Although widely dispersed and small in size on the coastal plain, sassafras becomes a more important component of the forest in the southern piedmont and Appalachian Mountains, where they can reach maximum heights of $30 \mathrm{~m}$ on the best sites (Griggs 1990; Koch and Smith 2008). Because of the clonal growth form of sassafras and apparent ability of $R$. lauricola to move in its lateral roots, it is possible that even low populations of X. glabratus could result in extensive mortality of this species. The ecological impacts of losses in this host are not yet known. However, due to their large distribution across the United States, significant losses of this species could affect forest tree composition and the wildlife that utilize this tree as a food source.

Redbay (s.s) was a common hardwood of the coastal plain and maritime hammocks. It can grow to a height of 18 to $21 \mathrm{~m}$ and a diameter of 60 to $90 \mathrm{~cm}$ (Brendemuehl 1990). Redbay (s.s) fruit serves as a food source for a variety of birds, rodents, bears, and other mammals. The tree's leaves are used by many insects as a host, including the specialized redbay psyllid (Trioza magnoliae Ashmead), the Palamedes swallowtail (Papilio palamedes Drury), and the spicebush swallowtail (Papilio troilus L.) butterflies, and therefore these may also be negatively impacted by laurel wilt (Lederhouse et al. 1992; Hall 2012, Hall and Butler 2013a, b). The range of the Palamedes swallowtail butterfly mirrors that of redbay (s.s) and concern over the declining host trees' populations led researchers to test the potential for host shifting from redbay (s.s) to camphortree (another species that supports larval development). Results indicated that the palamedes swallowtail does not discriminate between camphortrees and inanimate objects when choosing an egg-laying site, even though leaves fostered moderate levels of larval performance. This suggests that although the palamedes swallowtail could develop on camphortree, the chances for a successful host shift are minimal since the butterflies do not preferentially choose this tree species as an egg-laying site (Chupp and Battaglia 2014). In the absence of mature redbays (s.s), the palamedes swallowtail can survive on seedling and stump-sprouted material, which is abundant in much of the redbay (s.s) range affected by laurel wilt (Cameron et al. 2012).

As laurel wilt proceeds southward into the Florida Everglades, swamp bay populations have been severely affected (Rodgers et al. 2014). Aerial mapping of laurel wilt was conducted by the South Florida Water Management District (SFWMD) and the National Park Service (NPS) in 2011 and 2013. The 2011 aerial survey showed 4,925 ha coverage of laurel wilt, and by 2013 the coverage had increased to 133,740 ha (Fig. 14) (Rodgers et al. 2014). Concerns exists that invasive plants such as Brazilian pepper (Schinus terebinthifolius Raddi) and old world climbing fern (Lygodium microphyllum [Cav.] R. Br.) may quickly colonize the ecological niches once held by swamp bay (Snyder 2014; J. Smith, personal observation). In addition, the abrupt loss of tree island canopy can reduce peat accretion rates, which can lead to a loss of soil elevation, increased flooding, and additional stress to plant species (Cahoon et al. 2003). 


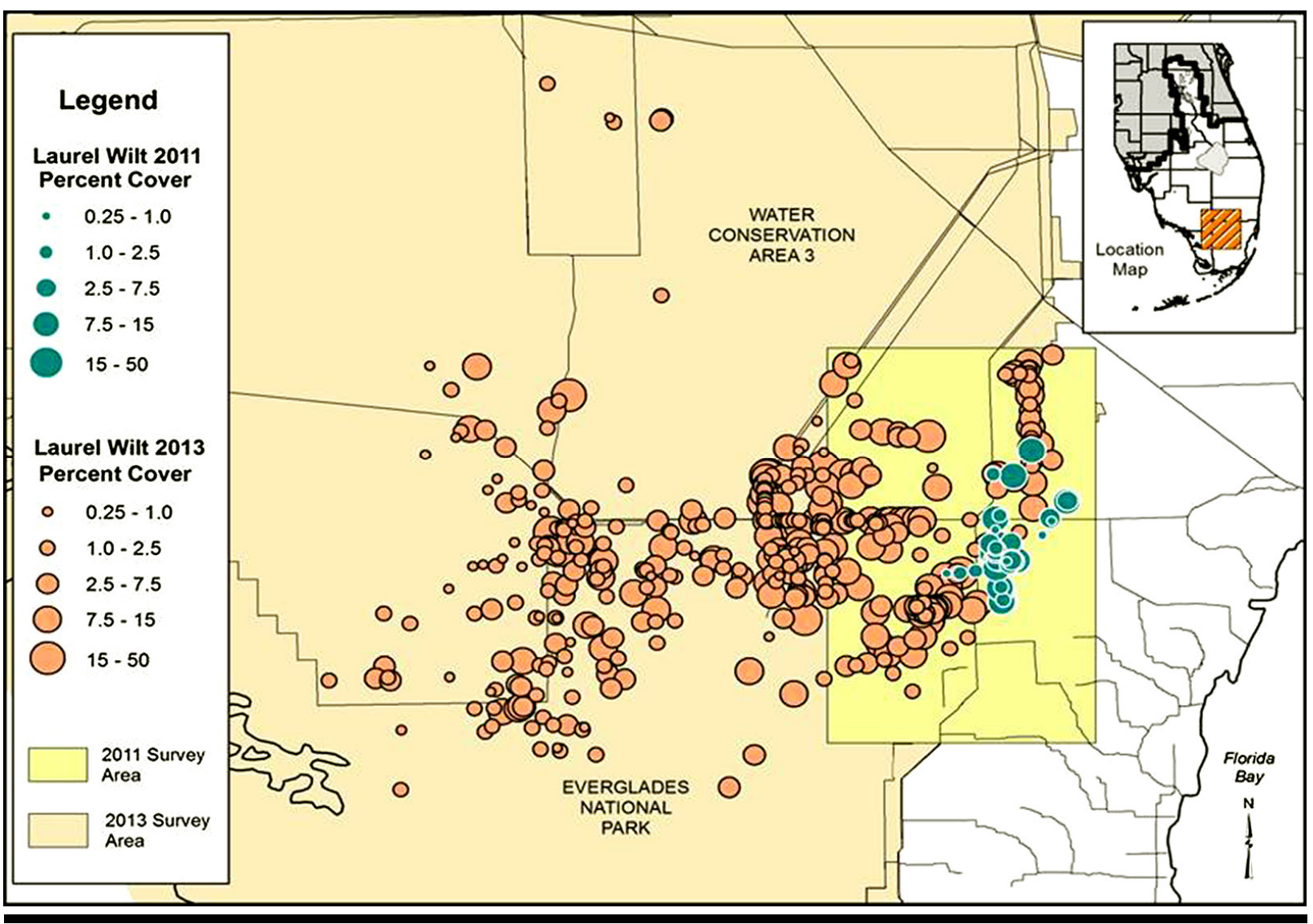

FIGURE 14

Florida Everglades laurel wilt distribution map for 2011 and 2013 (Adapted from Rodgers et al. 2014).

Surveys of wetland areas have reported mortality in the rare shrubs pondspice and pondberry due to laurel wilt, with $X$. glabratus using pondspice for brood material in Florida (Surdick and Jenkins 2009; Fraedrich et al. 2011; Hughes et al. 2011). Additional monitoring in Florida has found no evidence of laurel wilt within the state's natural populations of bog spicebush (Lindera subcoriacea B.E. Wofford), northern spicebush, and gulf licaria, although the latter two have been shown to be susceptible to $R$. lauricola via artificial inoculations (Fraedrich et al. 2008; Surdick and Jenkins 2010; Ploetz and Konkol 2013). Although susceptible to the pathogen, northern spicebush wood is not attractive to X. glabratus (Mayfield et al. 2013; Kendra et al. 2014a). Gulf licaria is represented as a single population in the United States (Simpson Park, Miami-Dade County, FL), where the establishment of laurel wilt within this tiny remnant population could result in extinction (Surdick and Jenkins 2010; Ploetz and Konkol 2013).

\section{Mitigation and Disease Management}

Laurel wilt is now firmly established in the United States and its eradication is not feasible. Management actions will focus on minimizing the effects of the disease within natural and residential areas, along with slowing its spread to new sites. Disease management options include the following.

\section{ERADICATION/SANITATION}

When laurel wilt was first detected on Jekyll Island (Georgia) in 2006, a concentrated effort was made to eradicate the disease from the island by the removal and burning of symptomatic trees within the natural and residential areas of the island. Due to the ability of $X$. glabratus to colonize the remaining large asymp- 
tomatic redbays (s.s) and freshly cut stumps (which were highly attractive to X. glabratus, J. Hanula, personal observation) on the island, laurel wilt returned by 2007 (Mayfield et al. 2009). Complete removal of laurel wilt and its vector may not be possible with sanitation methods alone, yet it could play a key role in the reduction of available brood material and $X$. glabratus population levels. Since large standing redbays (s.s) can foster the development and emergence of $X$. glabratus for over a year, removal and destruction of these trees may help suppress the disease (Maner et al. 2013). In addition, due to the widespread distribution of the pathogen within infected trees, as well as attack and cohabitation within these trees by generalist ambrosia beetle species, dead standing redbays present an opportunity for other species to acquire R. lauricola via lateral transfer (Carrillo et al. 2014).

Spence et al. (2013) found that chipping infested logs reduced X. glabratus emergence by 99 percent. Chip piles covered with plastic tarps yielded no $X$. glabratus beetles, suggesting that this is an effective method for preventing dispersal from infested host material. Raffaelea lauricola was successfully isolated from standing trees that had been dead for over a year (Spence et al. 2013) and X. glabratus can emerge from infested wood for over a year as well (Brar et al. 2013; Maner et al. 2013). Neither the fungus nor the beetle were recovered from wood after 2 days post chipping, suggesting that chipping greatly reduces pathogen and vector persistence in wood (Spence et al. 2013). Although reducing the likelihood of X. glabratus emergence, chipped material should not be transported to areas free of laurel wilt because some adults may survive the chipping process or may be attracted to or harbored in chip piles. Similar to previous recommendations for logs or fallen trees, chipped materials should be left on site (covered if possible) or taken to nearby municipal dumps where infested chips can be buried.

The removal of live or dead redbays in proximity to the rare and sub-optimal hosts pondspice and pondberry has been suggested as a way to reduce the number of $X$. glabratus in the area, to lower the probability of attacks on these threatened and endangered species (Fraedrich et al. 2011). Strategic coppicing of host trees may also allow small, discontinuous populations to exist, while allowing the regrowth of uninfected sprouts after the disease has passed. However, these measures are probably not feasible for large land areas.

To be effective, attempts at sanitation by removal of dead and infected host material will require constant monitoring of disease progression within affected areas and adjacent uninfected areas, along with coordinated action in a timely manner, which can be difficult in a forest setting. These methods have proven effective as part of an Integrated Pest Management program for Dutch elm disease in the northern United States, in which substantial differences in disease incidence existed between cities that did and did not implement some form of sanitation and disposal (Gibbs 2001).

\section{PROTECTION}

Various trapping studies have shown that $X$. glabratus generally flies within a few meters of ground level, with the majority of trap catches concentrated below $1.5 \mathrm{~m}$ on the trunk (Hanula et al. 2011; Brar et al. 2012). To evaluate the effectiveness of physically protecting the tree, screen barriers were used to exclude $X$. glabratus from accessing the lower trunk. Unfortunately, all screen-enclosed trees were killed by laurel wilt as beetles were able to bore through the barriers or simply attack the nonwrapped upper portions of the trunk (Maner et al. 2012).

Root graft transmission is suspected as a possible avenue of disease transmission in sassafras and avocado due to observed directional patterns of disease movement without evidence of beetle attack. As in other vascular wilt diseases (Dutch elm disease and oak wilt, caused by Ophiostoma novo-ulmi Brasier and Ceratocyctis fagacearum (Bretz) Hunt, respectively) disruption of root grafts is an effective way to 
halt disease spread from tree to tree (Epstein 1978). Severing root connections generally involves the use of heavy mechanical equipment (trenchers and rock saws). Although not currently applied as a management technique for laurel wilt, this method may be useful for sassafras, a species with an interconnected root system.

\section{CHEMICAL CONTROL}

Preventative control of laurel wilt on artificially inoculated redbays has been demonstrated through the use of the fungicide propiconazole, via root flare injections (macroinfusion) (Mayfield et al. 2008b). If done correctly, the macroinfusion process results in a uniform distribution of the fungicide within the tree, thereby resulting in protection of the whole tree. This treatment has been adopted by commercial arborists for the protection of high-value residential redbays (D. Spence, personal communication). Unfortunately, this protection has a limited duration of activity, with trees receiving the treatment often becoming vulnerable to laurel wilt within 1 to 1.5 years (A. E. Mayfield and D. Spence, personal communication). In theory, trees will require additional applications of the fungicide; however, little is known about how many treatments will be needed (and tolerated by trees) for long-term protection. Propiconazole has also been used therapeutically in Gainesville, FL, where a tree with laurel wilt ( $\leq 20 \%$ canopy) was saved by the removal of the infected branch about $1 \mathrm{~m}$ ahead of the vascular discoloration, a tree-wound sealant was used, and the fungicide was reapplied, resulting in the halt of wilt (J. Smith, personal communication).

Ploetz et al. (2011b) investigated the effects of other fungicides and modes of application (soil drenches and bark sprays) on potted avocado trees. Drench applications of fungicides such as demethylation inhibitors (DMIs) and thiabendazole were found to reduce laurel wilt development, with the triazole class of fungicides showing the greatest potential. Topical branch sprays of propiconazole with the surfactant Pentra-Bark (AgBio, Westminster, $\mathrm{CO}$ ) and triadimenol were also protecttive to potted avocados ( $1.5 \mathrm{~m}$ tall) inoculated with $R$. lauricola; however, this is not effective on large-diameter trees with thicker bark (R. C. Ploetz, unpublished)

Several synthetic insecticides have been tested for control of $X$. glabratus and other ambrosia beetle species in various assays with field-grown swamp bays, potted avocados, and avocado bolts. Zeta-cypermethrin + bifenthrin and lambda -cyhalothrin + thiamethoxam provided the most consistent control of these wood-boring beetles (Peña et al. 2011). A follow-up study was conducted to determine lethal concentrations $\left(\mathrm{LC}_{50}\right.$ and $\left.\mathrm{LC}_{90}\right)$ of selected contact insecticides, along with their persistence in Florida's field conditions, on avocado (Carrillo et al. 2013). In dipped-bolt assays, a concentration-dependent relationship was observed in the mortality of $X$. glabratus with most insecticides tested. Complete mortality of $X$. glabratus was observed at the second highest to highest test concentrations of bifenthrin, permethrin, fenpropathrin, z-cypermethrin + bifenthrin, and l-cyhalothrin + thiamethoxam, chlorpyrifos, and malathion. The percentage of X. glabratus found surviving in 15-day-old excavated galleries was also concentration-dependent for most insecticides. In field experiments, only malathion and z-cypermethrin + bifenthrin caused higher mortality than the control treatments after 15 days, but none of the insecticides affected X. glabratus mortality or boring activity after 22 days (Carrillo et al. 2013). Results from these experiments indicate that, although useful in X. glabratus suppression, the efficacies of these insecticidal treatments are short-lived. In addition, the threshold of unsuccessful protection of a live tree is a single beetle, and thus improvements in insecticidal control are needed before insecticides can be used as a stand-alone option. The use of fungicides and insecticides has merit in the protection of high value trees; however, their use on a forest or landscape scale is unfeasible due to costs, reapplycation needs, unknown effects to non-target species, and risks to the environment. 


\section{BIOLOGICAL CONTROL}

Research by Carrillo et al. (2015) describes the use of entomopathogenic fungi as a possible control measure for X. glabratus. Three commercial strains of entomopathogenic fungi (strain GHA of Beauveria bassiana Balsamo and strains Ifr 3581 and PFR of Isaria fumosorosea Holm ex Gray) caused mortality upon all X. glabratus beetles, with a median survivorship time of 3 to 5 days when dipped directly into a fungal spore suspension and incubated in vials. In boring assays, Xyleborus glabratus was able to construct galleries after contact with the entomopathogens; however, upon excavation, mortality was between 55 to $77 \%$ when dipped into the suspension or 71 to $83 \%$ when allowed to walk on the surface of logs that were previously dipped into the suspension. Although these treatments did not halt gallery formation, beetle mortality may occur before egg laying (approximately 7 days after boring), thus potentially lowering X. glabratus populations (Brar et al. 2013, Carrillo et al. 2015). Bait stations or sprayed trap logs are potential methods for delivery of these entomopathogenic fungi. Research is needed to describe the interactions of these entomopathogens with $R$. lauricola and whether they have the potential to halt fungal inoculation or disease.

\section{LIMIT MOVEMENT OF INFECTED WOOD MATERIAL}

Human-assisted movement of $X$. glabratus-infested wood was documented in Florida in 2008, when a citizen transported cut redbay logs from Duval to Volusia counties for wood turning purposes, unknowingly establishing a new disease focus within the county (A. E. Mayfield, personal communication). The movement of unprocessed wood has also been suspected in the appearance of laurel wilt in areas far from the leading edge of the disease front (e.g., in Alabama, Louisiana, Mississippi, and Texas). Progress has been made in educating the public on the environmental dangers of the movement of infested wood materials (see dontmovefirewood.org). The reduction of human-aided transport can have significant impacts in eliminating large jumps in the distribution of laurel wilt. Possible mechanisms for reducing the humanassisted spread of the disease include:

- restricting the movement of redbay or other documented hosts out of infected counties;

- increasing public awareness about the possibility of spreading laurel wilt through the movement of firewood and other unprocessed wood products;

- assessing the movement of unprocessed wood by the forestry industry to determine their possible role in disease spread; and

- encouraging rapid felling and chipping of trees killed by laurel wilt.

\section{HOST RESISTANCE}

A research program for the evaluation of natural resistance to laurel wilt in redbay (s.s) has been ongoing since 2007 at the University of Florida (Hughes 2013). In brief, researchers have established monitoring plots in areas of severe laurel wilt mortality in Florida, Georgia, and South Carolina. Asymptomatic trees $(>7.5 \mathrm{~cm} \mathrm{DBH})$ on these sites have been vegetatively propagated (Hughes and Smith 2014) and tested in disease screening trials (Hughes 2013). A few redbay (s.s) clones from South Carolina and Florida have demonstrated tolerance to laurel wilt in field trials, and additional trials are underway (Hughes 2013). Operational testing for the assessment of horticultural traits from these superior clones is scheduled for late 2015 (J. Smith, personal communication). Next steps include the use of these clones in pilot restoration studies in areas currently experiencing high rates of laurel wilt mortality to assess their performance under natural conditions (natural X. glabratus attack). Preliminary studies have begun to explore the possibility that surviving redbays (s.s) may lack volatile signals that render them attractive to the vector (Hughes et al. unpublished). 
Owing to the environmental impacts upon swamp bay in the Florida Everglades and upon tribal lands of the Seminole and Miccosukee Indians, germplasm presservation and resistance screening programs for this species are in development ( $\mathrm{J}$. Smith, personal communication). Sassafras may also be a candidate for disease resistance trials.

\section{CONSERVATION OF GERMPLASM}

A redbay seed collection and storage initiative by the USDA Forest Service National Seed Lab was started in 2007 to gather and test various long-term preservation methods (see Web Resources). Due to high lipid content, redbay seed can only be stored for approximately 24 months (at 1 to $2^{\circ} \mathrm{C}$ ) using traditional methods, with viability decreasing significantly with time (V. Vankus, personal communication). This scenario may also be true for other laurel wilt-susceptible species since seeds from members of the Lauraceae are generally temperature sensitive, and storage at sub-freezing temperatures usually results in seed mortality.

Vegetative propagation methods have been developed for swamp bay and redbay (s.s), making seed no longer the only focus of conservation efforts (Dehgan and Sheehan 1991; Hughes and Smith 2014). A germplasm collection of putatively resistant and susceptible redbay (s.s) clones has been established at University of Florida locations in Gainesville and at the Plant Science Research and Education Unit in Citra, FL. In addition to serving as a repository for living redbays (s.s) from ecotypes along the Atlantic Coastal Plain, inoculation trials have classified differing tolerance levels that can facilitate in-depth studies on resistance and host-parasitevector interactions among clones.

\section{INTEGRATED PEST MANAGEMENT IN RESIDENTIAL \& FOREST SETTINGS}

Slowing the spread of laurel wilt and protecting high-value specimens is possible. The best approach will rely on multiple integrated methods. The following techniques may be applied in the management of laurel wilt:

- monitoring and scouting for wilted or dead trees to assess the leading edge of the disease;

- sanitation by the removal and chipping of dead logs or trees;

- protection of high-value trees by the use of fungicides and insecticides;

- continued educational efforts on the impacts of the disease and how to prevent the spread of laurel wilt through the movement of infested wood combined with increased enforcement of statutes dealing with the movement of unprocessed wood;

- continued conservation of germplasm, development of resistant plant material, and alternative treatment methods.

\section{INTEGRATED PEST MANAGEMENT FOR NURSERY GROWERS}

At this moment, no specific research has been conducted on the management of laurel wilt within a nursery setting; however, the laurel wilt management strategies utilized by commercial avocado groves (Ploetz et al. 2011a) and those of commercial production nurseries for other ambrosia beetle species may be helpful (Reding et al. 2015):

- inspect all incoming and outgoing susceptible Lauraceae for evidence of laurel wilt or evidence of $X$. glabratus attack, with special attention to delineating between $X$. glabratus and other non-target species (such as Xylosandrus compactus);

- destroy laurel wilt-infected or X. glabratus-infested plant material by chipping or burning to reduce vector populations;

- protect large and/or high-value trees by the use of fungicides and insecticides; 
- monitor for X. glabratus with semiochemical lures on nursery property and adjacent wooded areas;

- increase vigilance in monitoring, chemical control, and sanitation during times of peak flight activity;

- situate susceptible plant material within the nurseries' interior and away from natural wooded areas; and

- utilize windbreaks to obstruct flight to susceptible hosts.

\section{Research, Extension, and Education Needs}

\section{RESEARCH NEEDS}

\section{Monitoring and Detection}

- Expand studies into the host-seeking behavior of the vector, while developing management techniques based on potential findings.

- Continue the development of improved lure systems for X. glabratus monitoring efforts.

\section{Chemical and Biological Control}

- Discover new chemical control methods (fungicides and insecticides), including the extension of efficacy for propiconazole macroinfusion treatments.

- Assess fungicides for therapeutic uses.

- Study the biology of X. glabratus in its native range and determine population-regulating mechanisms there, including natural enemies.

- Investigate potential biological control agents against the vector and/or pathogen.

\section{Resistance}

- Continue the development of resistant redbay germplasm and reintroduction techniques.

- Develop resistance screening programs for sassafras and other lauraceous hosts.

- Develop vegetative propagation methods for other host species.

\section{Host-Parasite-Vector Interactions}

- Investigate the role of root graft transmission for sassafras, avocado, and other species sharing a connected root system.

- Investigate molecular comparisons between R. lauricola and other closely related species to help discover possible virulence factors.

- Compare chemical and structural differences between members of the Lauraceae that have shown susceptibility and resistance to laurel wilt.

- Determine the role of other ambrosia beetle species in the laurel wilt epidemic and assess whether lateral transfer of the pathogen and transmission by other species is occurring under natural conditions.

\section{Epidemiology and Ecology}

- Investigate $X$. glabratus and R. lauricola interactions with hosts within its native range, and why laurel wilt does not occur in these regions.

- Delineate the susceptible host range of R. lauricola and X. glabratus within the Lauraceae around the world in order to forecast possible epidemics in other regions.

- Continue the development of disease-movement prediction models and assess potential movement out of the Atlantic Coastal Plain.

- Explore the disease dynamics within the Florida Everglades, in sassafras forests, and in rare hosts.

- Determine the effects of laurel wilt upon rare plant communities (pondspice, pondberry, and Gulf licaria) and possible conservation methods. 
- Determine impacts of laurel wilt epidemics on native flora, fauna, and ecological processes.

- Assess the natural long-range movement capabilities of $X$. glabratus.

- Continue research on the movement of unprocessed host wood by the general public and the forestry industry, their roles in disease spread, and possible management mechanisms.

- Conduct pathway analysis on how and from where the beetle and fungus arrived in the United States. Examine how to prevent the long-distance spread to areas such as the West Coast and Central/South America.

\section{EXTENSION AND EDUCATION NEEDS}

Various online sources of information about laurel wilt exist (see Web Resources). The dissemination of this knowledge will assist in creating a well-informed public. In addition, any movement of the disease into new and undocumented counties should be reported to local state forest health coordinators (see Infrastructure and Experts) so that confirmed new counties can be included on an updated distribution map. State, government, and university scientists and forest health personnel are encouraged to participate in meetings and workshops to educate other researchers, agents, or concerned groups and individuals about laurel wilt and management options.

Efforts should continue to educate the public and forestry industry about the potential dangers of the movement of firewood and unprocessed wood products and to suggest best management practices. Special attention should be given to providing informational material (pamphlets) on firewood movement to campgrounds and campground owners, and to making alternative methods of procuring safe wood at campground service desks and ranger stations freely available. Campers and residential homeowners should also be informed about the basic identification of laurel wilt, its symptoms, and management strategies. Much of this information has been provided in the web resources section.

\section{ACKNOWLEDGMENTS}

We would like to acknowledge the funding and support from the National Plant Disease Recovery System (NPDRS) of the USDA-Office of Pest Management Policy through Dr. Julius E. Fajardo. In addition, we would also like to thank Dr. Stephen Fraedrich (USDA-Forest Service) for his review of an early draft of this manuscript and Kelsey Olson for figure composition.

\section{References}

Bates, C. A., Fraedrich, S. W., Harrington, T. C., Cameron, R. S., Menard, R. D., and Best, G. S. 2013. First report of laurel wilt, caused by Raffaelea lauricola, on sassafras (Sassafras albidum) in Alabama. Plant Dis. 97:688.

Brar, G. S., Capinera, J. L., McLean, S., Kendra, P. E., Ploetz, R. C., and Peña, J. E. 2012. Effect of trap size, trap height and age of lure on sampling Xyleborus glabratus (Coleoptera: Curculionidae: Scolytinae), and its flight periodicity and seasonality. Fla. Entomol. 94:1003-1011.

Brar, G. S., Capinera, J. L., Kendra, P. E., McLean, S., and Peña, J. E. 2013. Life cycle, development, and culture of Xyleborus glabratus (Coleoptera: Curculionidae: Scolytinae). Fla. Entomol. 96:1158-1167.

Brendemuehl, R. H. 1990. Persea borbonia (L.) Spreng., Redbay. Pages 989-995 in: Silvics of North America. Vol. 2, Hardwoods. R. M. Burns and L. H. Honkala, eds. Agric. Handbk. 654. US Government Printing Office, Washington, DC.

Cahoon, D. R., Hensel, P., Rybczyk, J., Mckee, K. L., Proffitt, C. E., and Perez, B. C. 2003. Mass tree mortality leads to mangrove peat collapse at Bay Islands, Honduras after Hurricane Mitch. J. Ecol. 91:1093-1105.

Cameron, R. S., Bates, C., and Johnson, J. 2008. Distribution and spread of laurel wilt disease in Georgia: 2006-2008 survey and field observations. Georgia Forestry Commission, Dry Branch, GA. Retrieved 10 September 2015 from http://fhm.fs. fed.us/em/funded/09/so-em-08-02-report.pdf 
Cameron, R. S., Bates, C., and Johnson, J. 2010. Evaluation of laurel wilt disease in Georgia: Progression in redbay and sassafras 2008-2010. Georgia Forestry Commission, Dry Branch, GA. Retrieved 10 September 2015 from http://www.gfc. state.ga.us/forest-management/forest-health/laurel-wilt-disease/GeorgiaLaurelWilt Report2008-10.pdf

Cameron, R. S., Bates, C., and Johnson, J. 2012. Progression of laurel wilt disease in Georgia: 2009-2011 (Project SC-EM-08-02). Pages 145-151 in: Forest Health Monitoring: National Status, Trends and Analysis 2012. K. M. Potter, and B. L. Conlking, eds. Southern Research Station, USDA-ARS, Asheville, NC. Retrieved 10 September 2015 from http://www.treesearch.fs.fed.us/pubs/47199

Carrillo, D., Crane, J. H., and Peña, J. E. 2013. Potential of contact insecticides to control Xyleborus glabratus (Coleoptera: Curculionidae), a vector of laurel wilt disease in avocados. J. Econ. Entomol. 106:2286-2295.

Carrillo, D., Duncan, R. E., Ploetz, J. N., Campbell, A. F., Ploetz, R. C., and Peña, J. E. 2014. Lateral transfer of a phytopathogenic symbiont among native and exotic ambrosia beetles. Plant Pathol. 63:54-62.

Carrillo, D., Dunlap, C. A., Avery, P. B., Navarrete, J., Duncan, R. E., Jackson, M. A., Behle, R. W., Cave, R. D., Crane, J., Rooney, A. P., and Peña, J. E. 2015. Entomopathogenic fungi as biological control agents for the vector of the laurel wilt disease, the redbay ambrosia beetle, Xyleborus glabratus (Coleoptera: Curculionidae). Biol. Control 81:44-50.

Chief Billie, J. E. 2014. Beetles killing our 'Tu lee' must be stopped. Seminole Tribune Vol. XXXVIII, No. 2. Retrieved 10 September 2015 from http://www.semtribe.com /SeminoleTribune/Archive/2014/SeminoleTribune February\%2028 2014v2.pdf

Chupp, A. D., and Battaglia, L. L. 2014. Potential for host shifting in Papilio palamedes following invasion of laurel wilt disease. Biol. Invasions 16:2639-2651.

Coder, K. D. 2012. Redbay (Persea borbonia): Drifting toward oblivion. Warnell School of Forestry \& Natural Resources Outreach, Univ. of Georgia, Athens. Publ. No. WSFNR07-2. Retrieved 10 September 2015 from http://www.warnell.uga.edu/ outreach/pubs/pdf/forestry/Redbay\%20pub\%2012-9.pdf

Crane, J. H., and Smith, J. A. 2010. Homeowner detection of and recommendations for mitigating redbay ambrosia beetle - laurel wilt disease on redbay and avocado trees in the home landscape. HS1179. Univ. of Florida Inst. of Food and Agric. Sciences, Gainesville. Retrieved 10 September 2015 from http://edis.ifas.ufl.edu/hs1179

Dehgan, B., and Sheehan, T. J. 1991. Vegetative propagation of Florida native plants: VI. Persea palustris (Swamp bay). Proc. Fla. State Hort. Soc. 104:293-296.

Dixon, W. N., Woodruff, R. E., and Foltz, J. L. 2011. Black twig borer, Xylosandrus compactus (Eichhoff) (Insecta: Coleoptera: Curculionidae: Scolytinae). EENY311. Univ. of Florida Inst. of Food and Agric. Sciences, Gainesville. Retrieved 10 September 2015 from http://edis.ifas.ufl.edu/pdffiles/IN/IN57700.pdf

Dreaden, T. J., Davis, J. M., Harmon, C. L., Ploetz, R. C., Palmateer, A. J., Soltis, P. S., and Smith, J. A. 2014. Development of multilocus PCR assays for Raffaelea lauricola, causal agent of laurel wilt disease. Plant Dis. 98:379-383.

Epstein, A. H. 1978. Root graft transmission of tree pathogens. Ann. Rev. Phytopathol. 16:181-192.

Evans, J. P., Scheffers, B. R., and Hess, M. 2013. Effect of laurel wilt invasion on redbay populations in a maritime forest community. Biol. Invasions 16:1581-1588.

Fraedrich, S. W., Harrington, T. C., Rabaglia, R. J., Ulyshen, M. D., Mayfield III, A. E., Hanula, J. L., Eickwort, J. M., and Miller, D. R. 2008. A fungal symbiont of the redbay ambrosia beetle causes a lethal wilt in redbay and other Lauraceae in the southeastern United States. Plant. Dis. 92:215-224.

Fraedrich, S. W. 2008. California laurel is susceptible to laurel wilt caused by Raffaelea lauricola. Plant Dis. 92:1469.

Fraedrich, S. W., Harrington, T. C., Bates, C., Johnson, J., Reid, L., Leininger, T., and Hawkins, T. 2011. Susceptibility to laurel wilt and disease incidence in two rare plant species, pondberry and pondspice. Plant. Dis. 95:1056-1062.

Fraedrich, S. W., Harrington, T. C., and Best, G. S. 2015. Xyleborus glabratus attacks and systemic colonization by Raffaelea lauricola associated with dieback of Cinnamomum camphora in the southeastern United States. For. Pathol. 45:60-70.

Formby, J. P., Krishnan, N., and Riggins, J. J. 2013. Supercooling in the redbay ambrosia beetle (Coleoptera: Curculionidae). Florida Entomol. 96:1530-1540.

Gibbs, J. N. 2001. Vascular wilt diseases of trees: An Anglo-American perspective. Pages 15-28 in: Shade Tree Wilt Diseases. C. L. Ash, ed. American Phytopathological Society, St. Paul, MN. 
Goldberg, N., and Heine, J. 2009. A comparison of arborescent vegetation pre- (1983) and post- (2008) outbreak of the invasive species the Asian ambrosia beetle Xyleborus glabratus in a Florida maritime hammock. Plant Ecol. Divers. 2:77-83.

Gramling, J. M. 2010. Potential effects of laurel wilt on the flora of North America. Southeast Nat. 9:827-836.

Griggs, M. M. 1990. Sassafras albidum (Nutt.) Nees. Pagesin: Silvics of North America. Vol. 2, Hardwoods. R. M. Burns, and L. H. Honkala, eds. Agric. Handbk. 654. US Government Printing Office, Washington, DC.

Haack, R. A. 2006. Exotic bark- and wood-boring Coleoptera in the United States: Recent establishments and interceptions. Can. J. For. Res. 36:269-288.

Hall, D. W. 2012. Red Bay Psyllid, Trioza magnoliae (Ashmead) (Insecta: Hemiptera: Sternorrhyncha: Psyllidae) EENY-438. Univ. of Florida Inst. of Food and Agric. Sci., Gainesville. Retrieved 10 September 2015 from http://edis.ifas.ufl.edu/in799

Hall, D. W., and Butler, J. F. 2013a. Palamedes Swallowtail, Laurel Swallowtail, Papilio palamedes (Drury) (Insecta: Lepidoptera: Papilionidae) EENY-060. Univ. of Florida Inst. of Food and Agric. Sci., Gainesville. Retrieved 10 September 2015 from http:// edis.ifas.ufl.edu/pdffiles/IN/IN21700.pdf

Hall, D. W., and Butler, J. F. 2013b. Spicebush Swallowtail, Papilio troilus Linnaeus (Insecta: Lepidoptera: Papilionidae) EENY-168. Univ. of Florida Inst. of Food and Agric. Sciences, Gainesville. Retrieved 10 September 2015 from http://edis.ifas.ufl. $\underline{\text { edu/in325 }}$

Hanula, J. L., and Sullivan, B. 2008. Manuka oil and phoebe oil are attractive baits for Xyleborus glabratus (Coleoptera: Scolytinae), the vector of laurel wilt. Environ. Entomol. 36:1403-1409.

Hanula, J. L., Mayfield III, A. E., Fraedrich, S. W., and Rabaglia, R. J. 2008. Biology and host associations of the redbay ambrosia beetle (Coleoptera: Curculionidae: Scolytinae), exotic vector of laurel wilt killing redbay trees in the southeastern United States. J. Econ. Entomol. 101:1276-1286.

Hanula, J. L., Ulyshen, M. D., and Horn, S. 2011. Effect of trap type, trap position, time of year, and beetle density on captures of the redbay ambrosia beetle (Coleoptera: Curculionidae: Scolytinae). J. Econ. Entomol. 104:501-508.

Hanula, J. L., Sullivan, B. T., and Wakarchuk, D. 2013. Variation in manuka oil lure efficacy for capturing Xyleborus glabratus (Coleoptera: Curculionidae: Scolytinae), and cubeb oil as an alternative attractant. Environ. Entomol. 42:333-340.

Harmon, C. L. 2014. Standard Operating Procedure for Plant Diagnostic Laboratories, Laurel wilt and the redbay ambrosia beetle Raffaelea lauricola and its vector, Xyleborus glabratus, Version 2.0. Natl. Plant Dis. Recovery System. Retrieved 18 October 2015 from http://laurelwiltresearch.com/diagnostics

Harmon, C. L., and Brown, R. 2011. Standard Operating Procedure for Plant Diagnostic Laboratories, Laurel wilt and the redbay ambrosia beetle Raffaelea lauricola and its vector, Xyleborus glabratus, Version 1.0. National Plant Diagnostic Network. Retrieved 18 October 2015 from http://laurelwiltresearch.com/diagnostics

Harrington, T. C. 1981. Cycloheximide sensitivity as a taxonomic character in Ceratocystis. Mycologia 73:1123-1129.

Harrington, T. C., Fraedrich, S. W., and Aghayeva, D. N. 2008. Raffaelea lauricola, a new ambrosia beetle symbiont and pathogen on the Lauraceae. Mycotaxon 104:399-404.

Harrington, T. C., Aghayeva, D. N., and Fraedrich, S. W. 2010. New combinations in Raffaelea, Ambrosiella, and Hyalorhinocladiella, and four new species from the redbay ambrosia beetle, Xyleborus glabratus. Mycotaxon 111:337-361.

Harrington, T. C., and Fraedrich, S. W. 2010. Quantification of propagules of the laurel wilt fungus and other mycangial fungi from the redbay ambrosia beetle, Xyleborus glabratus. Phytopathol. 100:1118-1123.

Harrington, T. C., Yun, H. Y., Lu, S. S., Goto, H., Aghayeva, D. N., and Fraedrich, S. W. 2011. Isolations from the redbay ambrosia beetle, Xyleborus glabratus, confirm that the laurel wilt pathogen, Raffaelea lauricola, originated in Asia. Mycologia 103:10281036.

Hughes, M. A., Smith, J., Mayfield III, A. E., Minno, M., and Shin, K. 2011. First report of laurel wilt disease caused by Raffaelea lauricola on pondspice in Florida. Plant Dis. 95:1588.

Hughes, M. A., Shin, K., Eickwort, J., and Smith, J. A. 2012. First report of laurel wilt disease caused by Raffaelea lauricola on silk bay in Florida. Plant Dis. 96:910.

Hughes, M. A. 2013. The evaluation of natural resistance to laurel wilt disease in redbay (Persea borbonia). Ph.D. diss., University of Florida, Gainesville, FL.

Hughes, M. A., Brar, G., Ploetz, R. C., and Smith, J. A. 2013. Field and growth chamber inoculations demonstrate Persea indica as a newly recognized host for the laurel wilt pathogen, Raffaelea laurciola. Plant Health Prog. doi:10.1094/PHP-2013-0814-02-BR. 
Hughes, M. A., and Smith, J. A. 2014. Vegetative propagation of putatively laurel wiltresistant redbay (Persea borbonia). Native Plants J. 15:42-50.

Hughes, M. A., Black, A., and Smith, J. A. 2014. First report of laurel wilt, caused by Raffaelea lauricola, on bay laurel (Laurus nobilis) in the United States. Plant Dis. 98:1159.

Hughes, M. A., Inch, S. A., Ploetz, R. C., Er, H. L., van Bruggen, A. H. C., and Smith, J.A. 2015. Responses of swamp bay, Persea palustris, and avocado, Persea americana, to various concentrations of the laurel wilt pathogen, Raffaelea lauricola. For. Path. 45:111-119.

Hulcr, J., Mann, R., and Stelinski, L. L. 2011. The scent of a partner: Ambrosia beetles are attracted to volatiles from their fungal symbionts. J. Chem. Ecol. 37:1374-1377.

Hulcr, J., and Lou, Q. Z. 2013. The redbay ambrosia beetle (Coleoptera: Curculionidae) prefers Lauraceae in its native range: Records from the Chinese National Insect Collection. Fla. Entomol. 96:1595-1596.

Inch, S. A., and Ploetz, R. C. 2012. Impact of laurel wilt, caused by Raffaelea lauricola, on xylem function in avocado, Persea americana. For. Pathol. 42: 239-245.

Inch, S. A., Ploetz, R. C., Blanchette, R., and Held, B. 2012. Histological and anatomical responses in avocado, Persea americana, induced by the vascular wilt pathogen, Raffaelea lauricola. Bot. 90:627-635.

Jeyaprakash, A., Davison, D. A., and Schubert, T. S. 2014. Molecular detection of the laurel wilt fungus, Raffaelea lauricola. Plant Dis. 98:559-564.

Kendra, P. E., Montgomery, W. S., Niogret, J., Peña, J. E., Capinera, J. L., Brar, B., Epsky, N. D., and Heath, R. R. 2011. Attraction of the redbay ambrosia beetle Xyleborus glabratus, to avocado, lychee, and essential oil lures. J. Chem. Ecol. 37:932-942.

Kendra, P. E., Montgomery, W. S., Niogret, J., Deyrup, M. A., Guillén, L., and Epsky, N. D. 2012a. Xyleborus glabratus, X. affinis, and X. ferrugineus (Coleoptera: Curculionidae: Scolytinae): Electroantennogram responses to host-based attractants and temporal patterns in host-seeking flight. Environ. Entomol. 41:1597-1605.

Kendra, P. E., Montgomery, W. S., Sanchez, J. S., Deyrup, M. A., Niogret, J., and Epsky, N. D. 2012b. Method for collection of live redbay ambrosia beetles, Xyleborus glabratus (Coleoptera: Curculionidae: Scolytinae). Florida Entomol. 95:513-516.

Kendra, P. E., Niogret, J., Montgomery, W. S., Sanchez, J. S., Deyrup, M. A., Pruett, G. E., Ploetz, R. C., Epsky, N. D., and Heath, R. R. 2012c. Temporal analysis of sesquiterpene emissions from manuka and phoebe oil lures and efficacy for attraction of Xyleborus glabratus (Coleoptera: Curculionidae: Scolytinae). J. Econ. Entomol. 105:659-669.

Kendra, P. E., Montgomery, W. S., Niogret, J., and Epsky, N. D. 2013a. An uncertain future for American Lauraceae: A lethal threat from redbay ambrosia beetle and laurel wilt disease (a review). Am. J. Plant Sci. 4:727-738.

Kendra, P. E., Ploetz, R. C., Montgomery, W. S., Niogret, J., Peña, P. E., Brar, G. S., and Epsky, N. D. 2013b. Evaluation of Litchi chinensis for host status to Xyleborus glabratus (Coleoptera: Curculionidae: Scolytinae) and susceptibility to laurel wilt disease. Fla. Entomol. 96:1442-1453.

Kendra, P. E., Montgomery, W. S., Niogret, J., Pruett, G. E., Mayfield III, A. E., MacKenzie, M., Deyrup, M. A., Bauchan, G. R., Ploetz, R. C., and Epsky, N. D. 2014a. North American Lauraceae: Terpenoid emissions, relative attraction and boring preferences of redbay ambrosia beetle, Xyleborus glabratus (Coleoptera: Curculionidae: Scolytinae). PLoS ONE 9(7):e102086.

Kendra, P. E., Montgomery, W. S., Schnell, E. Q., Niogret, J., Deyrup, M. A., and Epsky, N. D. 2014b. Evaluation of seven essential oils identifies cubeb oil as most effective attractant for detection of Xyleborus glabratus. J. Pest. Sci. 87:681-689.

Kendra, P. E., Niogret, J., Montgomery, W. S., Deyrup, M. A., and Epsky, N. D. 2015 a. Cubeb oil lures: Terpenoid emissions, trapping efficacy, and longevity for attraction of redbay ambrosia beetle (Coleoptera: Curculionidae: Scolytinae). J. Econ. Entomol. 108:350-361.

Kendra, P. E., Montgomery, W. S., Deyrup, M. A., and Wakarchuk, D. 2015b. Improved lure for redbay ambrosia beetle developed by enrichment of $\alpha$-copaene content. J. Pest Sci. (in press).

Koch, F. H., and Smith, W. D. 2008. Spatio-temporal analysis of Xyleborus glabratus (Coleoptera: Circulionidae: Scolytinae) invasion in eastern U.S. forests. Env. Entomol. 37:442-452.

Kuhns, E. H., Martini, X., Tribuiani, Y., Coy, M., Gibbard, C., Peña, J., Hulcr, J., and Stelinski, L. L. 2014a. Eucalyptol is an attractant of the redbay ambrosia beetle, Xyleborus glabratus. J. Chem. Ecol. 40:355-362.

Kuhns, E. H., Tribuiani, Y., Martini, X., Meyer, W. L., Peña, J., Hulcr, J., and Stelinski, L. L. 2014b. Volatiles from the symbiotic fungus Raffaelea lauricola are synergistic with 
manuka lures for increased capture of the redbay ambrosia beetle Xyleborus glabratus. Agr. For. Entomol. 16:87-94.

Lederhouse, R. C., Ayres, M. P., Nitao, J. K., and Scriber, J. M. 1992. Differential use of Lauraceous hosts by swallowtail butterflies, Papilio troilus and $P$. palamedes (Papilionidae). OIKOS. 63:244-252

Maner, M. L., Hanula, J. L., and Braman, S. K. 2012. Evaluation of screen barriers on redbay trees to protect them from Xyleborus glabratus (Coleoptera: Curculionidae: Scolytinae) and distribution of initial attacks in relation to stem moisture content, diameter, and height. J. Econ. Entomol. 106:1693-1698.

Maner, M. L., Hanula, J. L., and Braman, S. K. 2013. Gallery productivity, emergence, and flight activity of the redbay ambrosia beetle (Coleoptera: Curculionidae: Scolytinae). Environ. Entomol. 42:642-647.

Maner, M. L., Hanula, J. L., and Horn, S. 2014. Population trends of the redbay ambrosia beetle (Coleoptera: Curculionidae: Scolytinae): Does utilization of small diameter redbay trees allow populations to persist? Fla. Entomol. 97:208-216.

Martini, X., Hughes, M. A., Smith, J. A., and Stelinski, L. L. 2015. Attraction of redbay ambrosia beetle, Xyleborus glabratus, to leaf volatiles of its host plants in North America. J. Chem. Ecol. 41:613-621.

Mayfield III, A. E., Smith, J. A., Hughes, M., and Dreaden, T. J. 2008a. First report of laurel wilt disease caused by a Raffaelea sp. on avocado in Florida. Plant Dis. 92:976.

Mayfield III, A. E., Barnard, E. L., Smith, J. A., Bernick, S. C., Eickwort, J. M., and Dreaden, T. J. 2008b. Effect of propiconazole on laurel wilt disease development in redbay trees and on the pathogen in vitro. Arboric. Urban For. 34:317-324.

Mayfield III, A. E., Barnard, E., Harrington, T., Fraedrich, S., Hanula, J., Vankus, V., Rabaglia, R., Duerr, D., Bulluck, R., Johnson, J., Bates, C., Cameron, S., Smith, J., Peña, J., Campbell, F., and Boone, A. 2009. Recovery plan for laurel wilt on redbay and other forest species. Natl. Plant Dis. Recovery System, Homeland Security Presidential Directive No. 9 (HSPD-9), USDA-ARS, Washington, DC. (Replaced by updated 2015 version) http://www.ars.usda.gov/research/docs.htm?docid=14271

Mayfield III, A. E., and Brownie, C. 2013a. The redbay ambrosia beetle (Coleoptera: Curculionidae: Scolytinae) uses stem silhouette diameter as a visual host-finding cue. Environ. Entomol. 42:743-750.

Mayfield III, A. E., MacKenzie, M., Cannon, P. G., Oak, S. W., Horn, S., Hwang, J., and Kendra, P. E. 2013b. Suitability of California bay laurel and other species as hosts for the non-native redbay ambrosia beetle and granulate ambrosia beetle. Agr. For. Entomol. 15:227-235.

Niogret, J., Kendra, P. E., Epsky, N. D., and Heath, R. R. 2011. Comparative analysis of terpenoid emissions from Florida host trees of the redbay ambrosia beetle, Xyleborus glabratus (Coleoptera: Curculionidae: Scolytinae). Fla. Entomol. 94:1010-1017.

Peña, J. E., Crane, J. H., Capinera, J. L., Duncan, R. E., Kendra, P. E., Ploetz, R. C., Mclean, S., Brar, G., Thomas, M. C., and Cave, R. D. 2011. Chemical control of the redbay ambrosia beetle, Xyleborus glabratus, and other Scolytinae (Coleoptera: Curculionidae). Fla. Entomol. 94:882-896.

Peña, J. E., Carrillo, D., Duncan, R. E., Capinera, J. L., Brar, G., Mclean, S., Arpaia, M. L., Focht, E., Smith, J. A., Hughes, M., and Kendra, P. E. 2012. Susceptibility of Persea spp. and other Lauraceae to attack by redbay ambrosia beetle, Xyleborus glabratus (Coleoptera: Curculionidae: Scolytinae). Fla. Entomol. 95:783-787.

Ploetz, R. C., Harrington, T., Hulcr, J., Fraedrich, S., Smith, J. A., Inch, S., Kendra, P., Mayfield III, A. E., Hanula, J., Rabaglia, R., Palmateer, A., Peña, J., Eskalen, A., Crane, J., Faber, B., Bostock, R., Harmon, C., Schnell, R., and Wingfield, M. 2011a. Recovery plan for laurel wilt of avocado (caused by Raffaelea lauricola). Natl. Plant Dis. Recovery System, Homeland Security Presidential Directive No. 9 (HSPD-9), USDA-ARS, Washington, DC. Retrieved 10 September 2015 from http://www.ars.usda .gov/research/docs.htm?docid=14271

Ploetz, R. C., Pérez-Martínez, J. M., Evans, E. A., and Inch, S. A. 2011b. Toward fungicidal management of laurel wilt of avocado. Plant Dis. 95:977-982.

Ploetz, R. C., and Konkol, J. 2013. First report of gulf licaria, Licaria triandra, as a suscept of laurel wilt. Plant Dis. 97:1248.

Ploetz, R. C., Hulcr, J., Wingfield, M., and de Beer, Z. W. 2013. Ambrosia and bark beetle-associated tree diseases: Black Swan events in tree pathology? Plant Dis. 95:856-872.

Rabaglia, R. J., Dole, S. A., and Cognato, A. I. 2006. Review of American Xyleborina (Coleoptera: Curculionidae: Scolytinae) occurring north of Mexico, with an illustrated key. Ann. Entomol. Soc. Am. 99:1034-1056. 
Reding, M. E., Ranger, C. M., Sampson, B. J., Werle, C. T., Oliver, J. B., and Schultz, P. B. 2015. Movement of Xylosandrus germanus (Coleoptera: Curculionidae) in ornamental nurseries and surrounding habitats. J. Econ. Entomol. 108:1947-1953.

Riggins, J. J., Fraedrich, S. W., and Harrington, T. C. 2011. First report of laurel wilt caused by Raffaelea lauricola on sassafras in Mississippi. Plant Dis. 95:1479.

Rodgers, H. L., Derksen, A., and Pernas, T. 2014. Expansion and impact of laurel wilt in the Florida Everglades. Fla. Entomol. 97:1247-1250.

Shields, J., Jose, S., Freeman, J., Bunyan, M., Celis, G., Hagan, D., Morgan, M., Pieterson, E. C., and Zak, J. 2011. Short-term impacts of laurel wilt on redbay (Persea borbonia L. Spreng.) in a mixed evergreen-deciduous forest in northern Florida. J. For. 109:82-88

Smith, J. A., Mount, L., Mayfield III, A. E., Bates, C. A., Lamborn, W. A., and Fraedrich, S. W. 2009. First report of laurel wilt disease, caused by Raffaelea lauricola on Camphor in Florida and Georgia. Plant Dis. 93:198.

Snow, A. M., and Stans, S. E. 2001. Healing plants: Medicine of the Florida Seminole Indians. Univ. of Florida Press, Gainesville.

Snyder, J. R. 2014. Ecological implications of Laurel Wilt infestation on Everglades Tree Islands, southern Florida. USGS Open-File Report 2014-1225. U.S. Geological Survey, Southeast Ecological Sci. Center, Gainesville, FL. Retrieved 10 September 2015 from http://pubs.usgs.gov/of/2014/1225

Spence, D. J., Smith, J. A., Ploetz, R. C., Hulcr, J., and Stelinski, L. L. 2013. Effects of chipping on emergence of the redbay ambrosia beetle (Coleoptera: Curculionidae: Scolytinae) and recovery of the laurel wilt pathogen from infested wood chips. J. Econ. Entomol. 106:2093-2100.

Spiegel, K. S., and Leege, L. M. 2013. Impacts of laurel wilt disease on redbay (Persea borbonia (L.) Spreng.) population structure and forest communities in the coastal plain of Georgia, USA. Biol. Invasions 15:2467-2487.

Surdick, J. A., and Jenkins, A. M. 2009. Pondspice (Litsea aestivalis) Population Status and Response to Laurel Wilt Disease in Northeast Florida. Florida Natural Areas Inventory, Tallahassee, FL.

Surdick, J. A., and Jenkins, A. M. 2010. Population surveys of rare Lauraceae species to assess the effect of laurel wilt disease in Florida. Florida Natural Areas Inventory. Div. of Forestry, Florida Dept. of Agric. and Consumer Services, Tallahassee. Retrieved 10 September 2015 from http://fnai.org/PDF/Population\%20Surveys $\% 20$ of $\% 20$ Rare $\% 20$ Lauraceae\%20Species\%20to\%20Assess \%20the\%20Effect\%20of\%20Laurel\%20Wilt \%20Disease\%20in\%20Florida.pdf

Whilby, L., Moncrief, C., and Dixon, W. 2012. Quarterly Reports No. 1 \& 2. Florida Coop. Agric. Pest Survey Program (CAPS). Div. of Plant Industry, Florida Dept. of Agric. and Consumer Services, Gainesville. Retrieved 10 September 2015 from https:// freshfromflorida.s3.amazonaws.com/pdf caps qtr 1-2-2012.pdf

\section{Infrastructure and Experts}

The following personnel have in-depth knowledge and/or experience with the laurel wilt disease system on redbay and other forest hosts:

\section{PATHOLOGY, MYCOLOGY}

\section{Marc Hughes}

University of Florida, School of Forest Research and Conservation

Gainesville, FL

352-846-0810, mhughes741@ufl.edu

\section{Jason Smith}

University of Florida, School of Forest Resources and Conservation

Gainesville, FL

352-846-0843, jasons@ufl.edu

Randy Ploetz

University of Florida, Tropical Research and Educational Center

Homestead, FL

305-246-7001, kelly12@ufl.edu 


\section{Stephen Fraedrich}

USDA Forest Service, Southern Research Station

Athens, GA

706-559-4273, sfraedrich@fs.fed.us

Thomas Harrington

Department of Plant Pathology, Iowa State University

Ames, IA

515-294-0582, tcharrin@iastate.edu

\section{ENTOMOLOGY, VECTOR}

James Hanula

USDA Forest Service, Southern Research Station

Athens, GA

706-559-4253, jhanula@fs.fed.us

Albert E. Mayfield III

USDA Forest Service, Southern Research Station, Asheville, NC

828-257-4358, amayfield02@fs.fed.us

Paul E. Kendra

USDA-ARS Subtropical Horticulture Research Station

Miami, FL

786-573-7090, Paul.Kendra@ ARS.USDA.GOV

Robert Rabaglia

USDA Forest Service, Forest Health Protection

Washington, DC

703-605-5338, brabaglia@ fs.fed.us

Daniel Carrillo

University of Florida, Tropical Research and Education Center

Homestead, FL

305-246-7000 ext. 231, dancar@ufl.edu

Jiri Hulcr

University of Florida, School of Forest Resources and Conservation and

Department of Entomology and Nematology,

Gainesville, FL

352-273-0299, hulcr@ufl.edu

\section{Lukasz Stelinski}

University of Florida, Citrus Research and Education Center

Lake Alfred, FL

863-956-8851, stelinski@ufl.edu

John J. Riggins

Mississippi State University, Department of Biochemistry, Molecular Biology, Entomology, and Plant Pathology,

Mississippi State, MS

662-325-2085,jriggins@entomology.msstate.edu

\section{EXTENSION}

\section{Carrie Harmon}

University of Florida, Southern Plant Diagnostic Network

Gainesville, FL

352-392-3631, clharmon@ufl.edu

\section{Aaron Palmateer}

University of Florida, Florida Extension Plant Diagnostic Clinic

Homestead, FL

305-246-7001, ajp@ufl.edu 
Jonathan Crane

University of Florida, Tropical Research and Education Center

Homestead, FL

305-246-7001,jhcr@ufl.edu

\section{OTHER}

Lissa Leege

Georgia Southern University, Statesboro, GA

912-478-0800, leege@ georgiasouthern.edu

\section{Joel Gramling}

The Citadel, Charleston, SC)

843-953-6459, joel.gramling@ citadel.edu

\section{STATE CONTACTS}

\section{Alabama}

\section{Dana Stone}

Alabama Forestry Commission, AL

(334) 240-9363, Dana.Stone@ forestry.alabama.gov

\section{Florida}

\section{Jeff Eickwort}

Florida Forest Service, Forest Health Section, Gainesville, FL 352-395-4689, Jeffrey.Eickwort @ FreshFromFlorida.com

\section{Timothy Schubert}

Florida Department of Agriculture \& Consumer Services

Division of Plant Industry

Gainesville, FL

352-395-4768, Timothy.Schubert@FreshFromFlorida.com

\section{Tony Pernas}

National Park Service

Palmetto Bay, FL

305-252-0347, tony_pernas@nps.gov

\section{Georgia}

James Johnson

Georgia Forestry Commission

Athens, GA

706-542-9608,jjohnson@gfc.state.ga.us

\section{Chip Bates}

Georgia Forestry Commission

Statesboro, GA

912-681-0490, cbates@gfc.state.ga.us

\section{Scott Cameron}

Georgia Forestry Commission

Richmond Hill, GA

912-663-2566, scameron@gfc.state.ga.us

\section{Louisiana}

\section{Brent Cutrer}

Department of Agriculture and Forestry

Baton Rouge, LA

225-925-4500,mcutrer@ldaf.state.la.us

\section{Mississippi}

\section{Randy Chapin}

Mississippi Forestry Commission

Brookhaven, MS

601-833-6621, rchapin@mfc.state.ms.us 


\section{North Carolina}

Rob Trickel

North Carolina Forest Service, NC

919-857-4858, Rob.Trickel@ ncagr.gov

\section{Kelly Oten}

North Carolina Forest Service, NC

919-731-7988, Kelly.Oten@ncagr.gov

\section{South Carolina}

\section{Laurie Reid}

South Carolina Forestry Commission

Columbia, SC

803-896-6140, lreid@ forestry.state.sc.us

\section{Southeastern U.S.}

Don Duerr

USDA Forest Service, Forest Health Protection

Atlanta, GA

404-347-3541,dduerr@fs.fed.us

Texas

Allen Smith

Texas A \& M Forest Service

Longview, TX

903-297-5094, lasmith@tfs.tamu.edu

\section{GERMPLASM CONSERVATION}

\section{Victor Vankus}

USDA Forest Service, National Seed Laboratory

Dry Branch, GA

478-751-3551, vvankus@fs.fed.us

\section{Jason Smith}

University of Florida, School of Forest Resources and Conservation, Gainesville, FL

352-846-0843, jasons@ufl.edu

\section{Marc Hughes}

University of Florida, School of Forest Research and Conservation, Gainesville, FL

352-846-0810, mhughes741@ufl.edu 


\section{Web Resources}

If web page addresses have changed since the time of publication, please contact the appropriate topic experts and/or state contacts (see Infrastructure and Experts) for further information about laurel wilt.

Alabama Forestry Commission

laurel wilt web page

http://www.forestry.alabama.gov/LaurelWilt.aspx?bv=3

Don't Move Firewood

laurel wilt web page

http://www.dontmovefirewood.org/gallery-of-pests/laurel-wilt.html

Florida Department of Agriculture and Consumer Services (FDACS)

laurel wilt web page

http://www.freshfromflorida.com/Divisions-Offices/Plant-Industry/Pests-

Diseases/Laurel-Wilt-Disease

Florida Department of Agriculture and Consumer Services (FDACS)

Rule 5B-65, Firewood and Unprocessed Wood Products

www.freshfromflorida.com/content/download/24082/487223/pdf firewood rule

backgrounder.pdf

Georgia Forestry Commission

laurel wilt web page

http://www.gfc.state.ga.us/forest-management/forest-health/laurel-wilt-

disease/index.cfm

Laurel Wilt Research web page

http://laurelwiltresearch.com

Louisiana Department of Agriculture and Forestry web page

http://www.ldaf.state.la.us

Mississippi Forestry Commission

laurel wilt web page

http://www.mfc.ms.gov/laurel-wilt.php

North Carolina Forest Service

laurel wilt web page

http://ncforestservice.gov/forest health/forest health laurelwiltfaq.htm

Florida Department of Agriculture and Consumer Services (FDACS)

Save the Guac

www.savetheguac.com

South Carolina Forestry Commission

laurel wilt information pdf

http://www.state.sc.us/forest/idwilt.pdf

Southern Plant Diagnostic Network

http://www.sepdn.org

Texas A \& M Forest Service web page

http://txforestservice.tamu.edu/default.aspx 
TexasInvasives.org

webpage to report laurel wilt

http://www.texasinvasives.org/action/report detail.php?alert id=19

United States Department of Agriculture (USDA)

Animal and Plant Health Inspection Service (APHIS)

plant pathogens web page

http://www.aphis.usda.gov/wps/portal/aphis/ourfocus/planthealth/sa import/sa permits/sa plant pests/sa plant pathogens/ct plant pathogens/!ut/p/a0/04 Sj9 CPykssy0xPLMnMz0vMAfGjzOK9 D2MDJ0MjDzd3V2dDDz93HwCzL29jA x8TfULSh0VAY 1WkE!/

United States Department of Agriculture (USDA)

National Invasive Species Information Center

laurel wilt web page

http://www.invasivespeciesinfo.gov/microbes/laurelwilt.shtml 